\title{
BETWEEN SCANDAL AND INVISIBILITY: INEQUALITY, HUMAN RIGHTS AND EFFECTIVENESS OF LAW IN BRAZIL (AND ITS SOCIOLOGY)
}

\author{
Pedro Henrique Ribeiro*
}

\begin{tabular}{l|l}
\hline RECEBIDO EM: & 17.6 .2020 \\
\hline APROVADO EM: & $\mathbf{2} .7 .2020$ \\
\hline
\end{tabular}

* Docente e pesquisador ("profesor media planta") na Universidad de Monterrey (UDEM México). Doutorando em Direito na J.W.Goethe Universität Frankfurt a.M. (Alemanha-DAAD). E-mails: ribeiroph@gmail.com e pedro.ribeiro@udem.edu. 
- ABSTRACT: The paper analyses the theoretical peculiarities and parallelisms of two themes in Luhmannian theory: (i) inclusion/exclusion and (ii) scandalous indignation by violation of human rights. It does so by (a) a loose approach of a "metaphorology"; more specifically the use of light and visual metaphors, alongside the limitations of such use; (b) and by elements of a legal sociology of scandal that checks some of the Luhmannian's affirmations on the theme. There is an overwhelming and peculiar presence of a quasi-literary rhetoric of visibility/invisibility, impressionistic revelation (evidence: "vedere", to see) of direct accessible "truths" and "light/shadow imagetics" in Luhmanns' texts on both of these themes. This is transferred to the secondary literature working with systems theory. The paper presents one possible internal exegetic explanation for such aporetic formulations as stemming from a dual conception of the basal problem "integration/differentiation". It results in the aporetic formulation of "two dark sides" of functional differentiation and consequently in two corresponding types of Luhmannian inspired legal sociology. Being firstly conceptualized for another context of discussion and presentation, the paper also addresses the same "light metaphoric" for the "Brazilian case" and the aporetic formulations of its sociology and its use by Luhmann himself. It further relates the theme with the "scandalous example" of Brazil and its (problematic and partial!) use for constructing comparisons in legal sociology, being a "Sonderweg" and "contrasting comparison case" (e.g. "Brazilianization of the West"). The paper presents, incidentally, some arguments for a further development of a legal sociology of the form "scandal".

- KEYWORDS: legal sociology of scandal; inclusion/exclusion; Niklas Luhmann; systems theory; metaphorology.

\section{ENTRE ESCÂNDALO E INVISIBILIDADE: DESIGUALDADE, DIREITOS HUMANOS E EFICÁCIA DO DIREITO NO BRASIL (E SUA SOCIOLOGIA)}

- Resumo: Este ensaio analisa peculiaridades teóricas e paralelismos de dois temas da teoria de Luhmann: (i) inclusão/exclusão e (ii) indignação escandalosa por violação dos direitos humanos. Para isso, o artigo (a) se vale de maneira bastante laxa de uma "metaforologia"; mais especificamente o uso de luz e metáforas vi- 
suais - apontando também para algumas limitações desse uso; além de valer-se (b) de elementos de uma sociologia jurídica do escândalo que se opõe a algumas afirmações luhmannianas sobre o tema. Há uma peculiar e representativa presença de uma retórica quase literária de visibilidade/invisibilidade, revelação impressionista (evidência: "vedere", "ver") de "verdades" diretamente acessíveis e imagética de "luz/sombras" nos textos de Luhmann sobre estes dois temas. Isto é transferido para a literatura secundária que trabalha com a teoria dos sistemas. O ensaio apresenta uma possível explicação exegética interna para essas formulações aporéticas que decorreria de uma dupla concepção do problema basal "integração/diferenciação". Isso resulta na formulação aporética de "dois lados negros" da diferenciação funcional, que poderia ser traduzida por dois tipos de preocupações da sociologia jurídica inspirada em Luhmann. Inicialmente conceitualizado para outro contexto de discussão e apresentação, o ensaio também aborda a mesma "metafórica da luz" para o "caso brasileiro" em suas formulações aporéticas, provenientes de parte (deveras problemática!) de sua sociologia e das referências ao "caso-típico-Brasil" pelo próprio Luhmann. O ensaio relaciona o tema com "exemplo escandaloso" do Brasil e a sua utilização (problemática e parcial!) para a construção de comparações em sociologia jurídica, sendo um "Sonderweg" e um "caso de comparação contrastante" (por exemplo, "Brazilianization of the West"). $\bigcirc$ ensaio apresenta, incidentalmente, alguns elementos que indicam a necessidade de um maior desenvolvimento de uma sociologia jurídica da forma "escândalo".

- Palavras-chave: sociologia jurídica do escândalo; inclusão/exclusão; Niklas Luhmann; Teoria dos sistemas; metaforologia.

\section{The Scandal Brazil - Inequality and the (sociology of) law between visibility and invisibility}

\subsection{Inequality and exceptionality}

To address (legal) sociology in and on Brazil, is to address the issue of the "scandal Brazil” (for the formulation, see GRÜN, 2011, p. 151). At least on the level of the so 
called "grand theories" (MERTON, 1968, p. 51), one can if so only scarcely bypass the perpetual "stumble stone" and the consequent "torments" that this "obstacle" poses to those that "venture" to describe this "exotic" Land, whilst trying to avoid its "traps" and being able to "come back alive" from its favelas to report back. ${ }^{1}$ Notably, that also applies for legal sociology.

On occasion of the so called "world events" World Cup and Olympic Summer Games (2014 and 2016) - and the accompanying mass protests, rushed evictions, crisis, corruption scandals, politically and legally controversial impeachment proceedings - Brazil has come once again to the center of the world mediatic stage and under the headlight of "international attention". ${ }^{2}$

Enter "scandal Brazil": A western Land of the so called "(semi-)periphery" of modernity with raging and huge economic and social inequality, treading a "singular" political, historical and cultural path, in the quintessential fashion of a Sonderweg-like-history, and with constant generalized corruptions scandals that are once again omnipresent in the media and public discourse, at least since 2013 up to the present date.

However, before referring to approaches on the inequality issue and on the "Sonderweg Brazil" (alongside with the complex perceptions, heated debates and thematizations that they imply), it must be laid clear right from the start: Elevated levels of social, ethnical and economic inequality in Brazil is indeed a scandalous reality. All the measurements that we can dispose of point out to a persistent unequal wealth distribution and institutional access in the Land - and that includes high rates of persistent racism and gender inequalities. That is also true "comparatively". Even if one admits that "the world" is in itself more unequal than Brazil domestically, Brazil ranks high up as one of the most unequal Lands "of the West" (as admitted by RADERMACHER, 2006). ${ }^{3}$ Even if the numbers seem to show a diminish-

1 These are all concepts attributed to the history of the concept scandal. See, item 3, below. The formulation of "coming back to report" is here meant not without some degree of irony. As we shall see below, even after warnings against a "exotization" of studies on Brazil's legal reality (LUHMANN, 1992b, p. 3-4), Niklas Luhmann uses a very "exotizicing" description of the hypothetical reports of "those who venture to go into the favelas of the third world and are able to come back alive" (LUHMANN, 1999).

2 For “international attention", in sociology, see LUHMANN, (1992a, p. 25 f, 1993a, p. 574). See also in relation to "scandal and normativity", LUHMANN, 1972, p, 62f, 65f. For a programmatic outlining of a possible "sociology of attention", see SCHROER, 2014.

3 The usual data come from both international indexes - such as GINI and HDR - Human Development Report -, and domestic ones, such as those from IPEA and PNAD. All of them, even with some differences, point out to Brazil as one of the countries with higher degrees of inequality in the "West". For an actualized and broad analysis of the last 
ing gap and a considerable reduction of extreme poverty, especially in the last 20 years or so (ARRETCHE, 2015), the inequality issue is still scandalously high in Brazil. One could safely argue, as Friedrich Müller (1997: 46f.; 2001: 74f, Neves, 2013: 52) once did while commenting on an analysis of constitutionalism in Brazil, that exclusion in "regions" such as in Brazil would assume a feature of "primary exclusion", with qualitative differences when compared to contexts of "secondary exclusion". This is, therefore, a relevant issue for "legal sociology" theorists, considering its destructive effects on the validity of the legal code.

The consequences of assuming this are quite considerable for theorizations, empirical studies and middle range theories. "Brazilian studies" usually (of course not exclusively) address, in a way or another, the consequences of inequality in a wide thematical range, both addressing diverse thematic fields and relying on multiple theoretical paradigms (see KNEER and SCHROER, 2009). Legal sociology is also influenced thereby.

Therefore, firstly, it is not by chance that many theoretical studies concerning political and legal sociology in Brazil regard some themes as being central, that gravitate around inequality, exclusion, "over-class/under-class" fragmentations of "citizenship" or destruction of the generalization of fundamental rights, such as: "constitutional reality or concretization" vs. "constitutional textuality or symbolism". The tension between "Brazilian reality" and "universalist modernity concepts" - especially when tackling inequality and its effects in institutions, law and culture - was and remains, for better or for worse, a varied and productive topos of sociology in and on Brazil. Even if some of these formulations, specially the "classical" ones, are considered by many to

50 years see ARRETCHE, 2015 and the contributions in this volume. Relating these data to obstacles conditioning the concretization and generalization of constitutionalism, see NEVES, 1992, p. 150, 159f, 1994, 2007a. Persistent inequalities in Brazil are also manifold and with developments of other deep-seated ascriptive foci of inequalities (terminology taken from PARSONS, 1970, p. 14-18), including regions, gender and ethnicity. For a theoretical analysis with empirical base on racial inequality and prejudice, see e SCHARCZ, 1993, 1998, spec. p. 213f and 242f, in English, see STAM and SHOHAT, 2012). For a report on "cordial racism", i.e. explaining how Brazilian racism would manifest itself also by "invisible and intimate" exclusions (not by legislation, for instance, as in the south of the USA and in Apartheid), but nevertheless violent and ever present, see FOLHA DESAO PAULO; 1995 . The term is referring to the "cordial man" as typical figure to explain the Brazilian ethos (HOLANDA, 1995, p. 60f). For a legal perspective on gender inequalities in legal professions in Brazil, see CUNHA et al. 2008. For inequalities and its relations to access to justice in relation to medicaments and cost of social rights see SILVA, 2008. For spatial segregation in discourse and in Brazilian cities' "fortified enclaves" and "gated communities" see CALDEIRA, 1996; for the consequences of inequality and spatial segregation (in "favelas" or areas of poverty) on the cities of Sao Paulo and Salvador de Bahia, regarding personal contact networks and access to market and economy, with extensive use of network analysis, see MARQUES, 2016. These references are meant to only give a scope of the problem, and are only a very selective overview. 
be overcome, the may also, in some extent, serve to positively broaden the conceptual scope of certain legal and political sociological concepts in a general sense, pointing out that "inequality" is considerably more complex than only an economical phenomenon, or, at least, that through the perspective of the sociologist, it does affect classical political and legal concepts (items 1.3 and 2.1, below). This does not correspond to arguing that this is only to be found in Brazilian studies. Of course, the sociologies of inequality are great and varied in different fields and regions of the globe. It is here brought only to stress one marking feature of (legal) sociology in Brazil, that usually concerns the (lack of) generalization of fundamental rights mainly due to exclusion(s) and inequality, or due to Brazilian cultural-political "singularities".

But if it is correct, sociologically, that exclusion reduces persons, as communication addressees to mere bodies (LUHMANN, 1995d), rendering, in an exclusion spiral, the inclusion to all functional systems extremely unlikely (LUHMANN, 1995c); one could say, as many do, that the excluded are rendered "invisible" to social systems (LUHMANN, 1997, p. 631). In a conceptual sociological terminology, without using the "visual" metaphor (NEVES, 1992, p. 94f, 1994), the "excluded" are then under-integrated or under-included, mainly on the level of access to the positive performances of social systems, being "invisible", for instance, to rights implementation of the legal system, whereas extremely "visible" on the level of the dependency performances of these systems, e.g., sanctions and police enforcement in the legal system. Correspondently, if the legal system is also selective regarding the over-included (or over-integrated) "elites", one could say that these parcels of the population are rendered invisible to the coercions and rules (dependency) of the legal system, as usually affirmed by the "invisibility and scandalous impunity of corruption" (O'Donnell, 2000, p. 346). Conversely, the "over-included" are visible and included in relation to the positive performance of social systems (access). The legal order becomes then "highly selective" (HABERMAS, 1999, p. 226).

Furthermore, one could argue that the very notion of inequality itself (a relational concept) is also said to be "invisible" and "naturalized in daily life in Brazil", not being part of political discourse; resulting, in the end, in political invisibility (SOUZA, 2006, p. 40 KÜHN and SOUZA, 2006, p. 18f). As conceptualized by Neves (1992, p. $166 \mathrm{f}$ and 1994), the point is that these relations go through a generalization in a daily basis on the expectational structural level of "acting" and "expecting”. On the level of systems' theory, it has already been stated that "exclusion" itself was a "logical shadow" (LUHMANN, 
1995c, p. 244). Notwithstanding, on the other hand, exclusion (and inequality) are often described, in Brazil and abroad, as being a reality "in plain sight", "accessible to the naked eye" (LUHMANN 1999, p. 147 f) - mainly with the use of metaphors of visibility and rhetoric of evidence. Brazilian inequality would be not only shockingly visible but also a common knowledge shared perception able to justify the "Brazilianization Theorem" (BECK, 1998, 2007, p. 28) almost without further argumentation needed (item 1.5).

The thematization of exclusion (and implicitly also inequality) through this tension between visibility and invisibility can be retraced in Niklas Luhmann's system's theory. Here, the crucial importance of legal sociology, references to Brazil, and the metaphorical argumentation were key in shaping the debate and setting forward changes and developments in the theory (see RIBEIRO, 2013). This essay traces some of those changes (Item 2), but does so mainly to argue that it can be a model for understanding a specific mode of comparison using Brazil and approaching main "thematical fields" of Brazilian and Latin American (legal) sociology (item 1.3, 1.4). The analysis aims to show how the "exclusion debates" within Luhmann's theory are prone to a specific use of metaphor and "scandalization" with the use of Brazil. Some methodological issues of comparison modi in theory are then discussed and applied to the study of Brazil as a “(negative) stereotyping” (BECK, 2007, p. 138) or a "contrast foil” ("Kontrastfolie” - SCHNEIDER, 2011, 2015) and evidence-rendering example.

Nevertheless, secondly, Brazilian inequality is also said to be understood, at least from the viewpoint of the theoretical sociologist and culturalist, as a quite singular one. Here, the historical and cultural contexts come to the foreground. Brazilian political history and cultural specificities come at play in setting the background for sociological theorizations on the Land. One recurrent trace of Brazilian (and Latin-American) sociology was precisely to address these long term political cultural traits that would make Brazil singular and modern. Here one faces the long-term debates on the thesis of "singularity" (or Sonderweg) in sociological descriptions of Brazil. These perceived peculiarities or exceptionalities, sometimes taken as “deviations”, (TAVOLARO, 2011. pp. 91 e ss.) foster a great deal of fascination and "exotization" (on race, and the concept of "spectacle of races" and "laboratory" see SCHARCZ, 1993, esp. p. 11f). If the singularity emphasis is a perceived recurring theme in Brazilian studies and "social thought", one can also observe in the academical, cultural and popular discourse, both internationally as in Brazil itself, numerous uses of Brazil as an example to scandalize issues of public policy and legal reforms, as well as to produce "evidence" and support 
to theoretical arguments, as we shall see in the "Brazilianization" discourse, bellow. These issues, however highly prone to critique, have also positively mobilized debates and the reception of theories applied to specific problematizations not always reduceable to "national methodologism", and that cannot be only reduced to a negative aspect (items 1.5 and 2.1).

\subsection{Visibility, Scandal and Metaphors}

The visibility metaphor and the scandal are, then, the main motives of this essay. They are mobilized to tackle some of those "substructures of thinking" (BLUMMENBERG, 1997 p. 13) that permeate (legal) sociology in and on Brazil. Considering that "the concept cannot render possible all of that, which reason demands" (BLUMMENBERG, 2007), this essay sets out to demonstrate two metaphorical topoi usually associated with Brazilian studies, both used to render evidence and plausibility in their argumentation and presentation. They are, on the one hand, metaphors of visibility and light, usually consider the issue of inequality and exclusion (item 2.1), and, on the other hand, the topoi of the scandal, (items 1.5 and 3), something that perform similar argumentative functions. ${ }^{4}$

One should note, that at least since the works of BLUMMENBERG (esp. 1997 and 2007), a great deal of studies considers the use of metaphors in science and theory as not being merely rhetorical, i.e. opposed to "concepts" or "reason". In this essay, instead of discussing the gains and limitations of the recurrent traits in theorizing Brazil through "specification (Sonderweg-Topos), scandalization or metaphorization", an argument is set forward to address at the same time how "scandal topoi" are used in Brazilian studies, and reversely, in a provocative fashion, how the use of the "Brazilian Sonderweg in democratic transitional human rights" (SCHNEIDER, 2011, 2015) could be used as a deconstruction of some general theories that link scandalizations to the validity fundament of human rights (item 4).

4 One could argue that the seemingly "eclectic" overview of broad sociological problems in different themes and periods should be considered to "broad" for a book on "legal sociology" (or, in German, Rechtssoziologie). This is also something that sees this discipline as being one mainly set forth by legal scholars interested in sociology, whereas the "Law and society" studies would be the label for an eclectic mishmash of all possible social sciences perspectives with any relation to Law. All these distinctions seem to be extremely arbitrary and intending to draw disciplinary boundaries where there are none to be found. (For a comprehensive description of the field and its obstacles and challenges in Germany, including professionally, see the article, written in English, BORA, 2016).

5 (see, for sociology, see the compelling arguments from LÜDEMANN, 2004, and applying Lüdemann's concept of “Leitmetaphorik" to the pair visibility-invisibility in Luhmann's exclusion studies, FARZIN, 2008. 
BETWEEN SCANDAL AND INVISIBILITY:

It is not an aim of this study to address the relative merits of comparison modes in theory-building, nor to engage with the thesis of "singularity"; "peripherical modernity context". Thought to be a part of a book on legal sociology in and on Brazil, it seems to suffice if this essay could present, albeit only panoramically, some recurring characteristic background themes and approaches in this tradition and, at the end, develop constructive provocations, on how this stereotypical "sociological use" of Brazil as "scandalizing example" and "negative contrast folio", however problematic and simplifying it may be, could also be made productive for the debates.

\section{3 "Sonderweg-Brazil" and its influence in "Law and Society" studies: The singularity of Brazilian reality as a "curious twilight" and the "lighthouse" of social theory}

Firstly, to understand the use of the singularity thesis and, more importantly, to stress how "singularity" is always one side of a comparison (see RIBEIRO, 2013), one could start with some very broad, well known features of Brazil's history -i.e. embedded in common knowledge. The Brazilian peculiar path, its Sonderweg, would be crudely characterized as such: Brazil is a Land of continental proportions, the only Portuguese-speaking one in America. Differently from many of its counterparts in Ibero-America, its colonization was one of primarily of slavery (first Indigenous - but resulting primarily in genocide-, then extensively African). It followed primarily the plantation regime of extensive extraction and culture cycles in great portions of land property - the so called latifundia -, where the primary colonization pattern was not one of building a middle class (as we can see, for instance, by the very late introduction of universities in the Land, CARVALHO, 1987).

In 1808, we are faced with the quite peculiar "inversion of the metropolis" when, fleeing Napoleon, the Portuguese Court, with correspondent infra-structure and incentives, settled in Rio de Janeiro, therefore "raising" the status of Brazil to a "co-Kingdom" in 1815. That increased immigration and the Land's new status changed somewhat the social and economic structures of Brazil. Nevertheless, contrasting with the near region, the independence of Brazil (1821) was not one primarily of conflict and war, but followed the "liberal revolutions in Portugal" demanding the return of the Royal Family. The son of the King of the United Kingdom of Portugal, Brazil and the Algarves became the Emperor of Brazil, with the institution of the Poder Moderador (moderating power) ascribing 
personal and private attributions to Pedro I(1822-1831) and Pedro II(1831-1889). Brazil followed to be the last western Land to abolish Slavery, in 1888.

After the abolition and the proclamation of the Republic (1889), a great disregard to the newly freed slaves and an incentive to (mostly but not only) European immigration followed, in a context of a growing nationalism, "modernization" (in the model of European societies) and ambivalent incentive to "miscegenation" (or better, a "Europeization" or "an ideal whitening" of the population - see SKIDMORE, 1974, Ch. 4). Another "peculiarity", was that Brazil was a Land characterized by miscegenation, ambiguously seen sometimes as a cause of weakening and ruin, but also other times through a "positive register" of peacefulness and racial democracy - something that was debunked by social movements and Brazilian sociology. ${ }^{6}$

However, it was with the centralizing proto-fascist "Estado Novo" and Getúlio Vargas that the Sonderweg-Brazil-discussions gained greater momentum. In the 30ies there was a great increase in nationalism, bureaucracy-building and centralization. Even now, many say that the "entering" of Brazil in modernity began in the period even though this is disputed (see TAVOLARO, 2011). In any case, the issue of "forming" the people and the nation was at the center of the debates. A great deal of thinking was centered in the notions that Brazil did not have an ideal, active people, something said to be a permeating trait on Brazilian political and social thought, gaining even the label of the "negative hypothesis" (BRANDAO, 2005). In Brazil, one would only find a people that had only "bestialized" watched the independence (CARVALHO, 1987) and over which one had the need to form via State centralization an integrated people from “amorphous masses” (VIANNA,1973, esp. p. 123 f). These issues predate the discussions of the 30ies, but it was then that it assumed more clear contours of differentiated social thought and debates.

One of the key issues was the "construction of modern citizenship" in the period. Around the time of Getúlio Vargas' Government, the Brazilian singularity was later

6 This contributed for the myth of a peaceful "racial democracy", "social harmony", "peaceful miscegenation", - and to the assumption that in Brazil there would be none "racial pride" (HOLANDA, 1995, p. 53); something that the social sciences and the Black Movement in Brazil have struggled to debunk (see, for an overview, among many, SCHWARCZ, 1998, p. 128f, $202 \mathrm{f}$ ) Schwarcz reminds us that this was true both internally and externally and that even UNESCO funded in 1951 a study on "racial democracy" in Brazil, a premise preemptively contested by sociologists of the country such as Florestan Fernandes. Before that, the myth of "racial democracy" and of the festive and peaceful people had already been also reinforced by literary and travel report works that even attested that Brazil should be an example for Europe in "ignoring the validity of race” (ZWEIG, 2013[1941], p. 17f). For an overview in English, with encompassing analyses of Brazilian social thinking and culture analysis, see STAM and SHOHAT, 2012, esp. p. 31f, 185f). 
described as in comparison to T. H. Marshall's theory of citizen formation and on debates following the "chronological" order of civil, political and social rights. Some studies on models of democracy pointed to the idea that instead of a citizenship (cidadania), the Brazilian institution development would imply in contrast a "statezenship" (estadania) in "a top-down non-participatory model” (CARVALHO, 1996, 2001). This top down model with some level of guaranteed social rights coexisting with elevated levels of political repression (lack of political rights) and suffocation of autonomous civil society organizations could characterize the realm of politics in Brazil as "drowned in Laws” (FRENCH, 2004). Nevertheless, the idea that the Vargas period would be a key feature in shaping citizenship and political culture in Brazil could also be countered for being an "hegemonically shared discourse", alongside explications of great historical tendencies that followed "economic dependency" and "patrimonial-patriarchal inheritance” in determining political sociability in Brazil (TAVOLARO, 2011, esp. p. 192).

The "Brazilian social thought" also gained momentum around the 30ies. Not only the institutional and historical peculiarities were in the foreground. Ours would be also a cultural singularity. Here, the long-lasting effects of inequality and remnant structures of slavery are studied also under the label of "culture". If one looks at studies that approaches cultural elements, such as the many that analyze the "amortization" and "conciliating" characteristics of "the culture" in Brazil, one encounters a wide array of "singularities", especially in those studies concerning the formation (or lack thereof) of Brazil as a nation. In a wide field of discussion in Brazilian social sciences since the 1930s, one notes already a complex set of "lineages" (BRANDAO, 2005) often referred to, posteriorly, as "Brazilian social thought" or "Brazilian Political thinking" that goes way beyond, in variety and in depth, then simply asserting the already internationally famous cliché of the Brazilian "malandro" (for a comparison with the literary archetypical "trickster", but in Brazilian context, see CANDIDO, 1970).

Very broadly speaking, this is thought to be a Land where, at least in its "formation", all antagonisms meet - economic, social, political and cultural, local and global -, but that dwells in and fosters permanent and intricated "antagonisms equilibria", in a cultural hybridism where violence and intimacy would walk together (FREYRE, 2003). Where the "environment" exerted a greater force in shaping "culture" as the other way around (VIANNA, 1973). Where not only violence, but also institutions where constantly permeated by the ideal type of the "cordial man", with his personal-oriented bonds rendering rationalism and even democracy a great "mis- 
understanding”(HOLANDA, 1995). Personality networks, favor relations, patriarchal domination, corruption and patron-client relations are present in many of the conclusions drawn thereupon. ${ }^{7}$

The influent literary critic Antonio Candido formulated this thesis while commenting on the novel "Sargento de Milícias" in a very cunning way to express this "general accommodation, which dissolve the extremes": The novel would reflect the Brazil of intimate connections of the public and formal, on the one hand, with the private and informal, on the other hand, in a constant dialect of order and disorder. In it, no clear-cut or binary distinction would be possible or make practical sense; such as, e.g., in the "dancing circularity" between lawful/lawless. He argues that

[...] one of the greater efforts of all societies (and their sustaining ideologies) is to presuppose the objective existence and the real valor of antithetical pairs, in which one is always forced to choose from (lawful or lawless; true or false, moral or immoral, just or unjust) (...). Precisely because of that there are parallel developments of casuistic accommodations that make hypocrisy a pillar of civilization. And it is one of the great functions of satiric literature, of demystifying realism and of psychological analysis, to show, each one in their own manner, that the referred pairings are reversible, not static, and that outside of the ideological rationalization the antinomies live with each other in a curious twilight (CANDIDO, 1970, p. 78; 82; 87. Emphasis added. See also ROCHA, 2004).

The great "explanations of Brazil", mainly due to the influence of the sociological essay-style of the 1930es, were focused on the specificities of the country and were characterized by the expropriation of "themes and problems" that led authors to "explore certain perspectives of reading the past" in the search for the national identity (LAVALLE, 2004, pp. 69-70). Many of these explanations were characterized by referring to crystalized remnants of the past, in historical continuities that worked as broad and totalizing explanations. They usually highlighted the anomalous, pre-modern and backward character of Brazil, as the analysis of the national character through the Iberic ethos (VILLAS BOAS FILHO, 2009, p. $187 \mathrm{ff}$.) and the public ethos to describe the failure in constituting a collective public space in the country (LAVALLE, 2004).

7 The expressions of the tensions of the singular (Brazilian, local) and the general ("modernity", global universality) were very different and manifold both in political positions and theoretical frameworks (hence the use of "lineages” by BRANDAO, 2005). 
BETWEEN SCANDAL AND INVISIBILITY:

"Brazilian social thought” (BRANDAO, 2005) comprised also different and opposing political agendas that centered themselves around a shared problem: founding the Brazilian nation or to show blockages and challenges for its "modernization". Some say this latter spread to a broad spectrum of Brazilian academical research, resulting, in the end, in a "nationalist methodological bias" (DOMINGUES, 2011, p. 8 and 89). The background problem was not only the theoretical explanation of Brazil, but also the political oriented description of the nation in view of the problem of facing "backwardness" and insert it in the modernity, serving as a "lighthouse" to national identity and political thinking in "imagining our nation" (SANTIAGO, 2002, p. xxii).

The topoi of "economic dependency" and far reaching, development-blocking "patrimonial-patriarchal" domination are once again usually deployed to address the so-called "democratic-interval” period of 1945-1964, considering it as only epidermically democratic, especially considering the vital entanglement of politics and polity with elites - if not only rural, also bureaucratic (see FAORO, 1994, p. 80). Many said (see CAMPELLO de SOUZA, 1976, p. 64ff.) that the "democratic transition" after 1945 (with the Constitution of 1946) was to be understood more as driven by the external geopolitical context of the post-war, being institutionally better characterized as a prevalence of continuity on the administrative plane, not implying a radical democratization (from another theoretical perspective, see the concepts of "nominalist and symbolical" constitutionalism for the period in NEVES, 2007a, 182f).

The Military Dictatorship (1964-1988) period would once again reinforce the model of political repression and centralization, non-participation (or highly repressed autonomous organization), violation of human rights, State-centered “modernity" from above and the accompanying blockings on liberal democracy development, generalization of (active) citizenship, fostering of civil society organization and deepening of a democratic, pluralistic public sphere.

This scenario marked also the discussions on the re-democratization period (1988) and entered the terrain of theories of fundamental rights and constitutionalism. One recurring argument to be found is that even if formally remodeled, the democratic period would have to face the longe durée constrains in Brazilian "political culture" and "institutional development", where the institutional changes should be considered as only shallow and of accommodating (incident, non-radical) change, living alongside a political culture (and informal determinants of institutions) prone do patriarchal-patrimonial domination and social segregation of remnants of slavery and its cultural and 
institutional long term effects. In the fashion of "changing constantly to remain the same," as in the novel Il Gattopardo, ${ }^{8}$ the "long political trait" of Brazilian political history could be summarized in the transition description given by the motto attributed to the General, Ex-President of Brazil in the Military Dictatorship, Ernesto Geisel (1974-1979) of a "slow, gradual and safe change"; something that was read by many as a "pseudo" or non-effective or radical institutional change.

After the Constitution of 1988, many debates argued that the constitutional system that followed was also a result from a (too) great pact, symbolically comprising many different opposing political programs and therefore "unpractical". The singularities were also attributed to the argument that the constitutional system of the Federal Constitution of 1988 was accordingly "too large". This "thick" constitution would result in a constitutionalization overburden and foster ungovernability (see TUSHNET, 2000, Ch. 1, and the critiques in COUTO and ARANTES, 2006). This would result, furthermore, in a patchwork mixt system that would give incentives to an inconsistent "decision-making paralysis" followed by "hyperactive” populism (LAMOUNIER, 1994, p. 31). The constitutional order would be singularly thick and patchworked, and, if one allows the comparison, resulting in a (dysfunctional und "undecided") "antagonism equilibria" of political programs and frames. The generalist approaches considering sociological and economical determinants to explain the functioning of the 1998 constitutional order in Brazil received also reactions. (see the neo-institutional approach of the "coalition presidentialism" in FIGUEIREDO and LIMONGI, 1999, esp. p. 9f).

Alongside this description, it is also stated to be a feature of Brazilian democracy the assumption that it would be "formally granted", but not actually shared and experienced in its "political culture" (ALMOND and VERBA, 1963, p. 13f), nor it would be deeply rooted in generalized political trust from the citizens in democratic institutions (MOISÉS, 1995) or in the public sphere (NEVES, 2006, p. 139 ff.). This argument, also comparative in its nature, was fruitfully put forward by Guillermo O’Donnell, who develops the analytical difference between only formally institutionalized democracy and “deepened” or “consolidated” ones (O’DONNELL, 1988). These thesis, one must

\footnotetext{
8 "Se vogliamo che tutto rimanga com'è bisogna che tutto cambi." (in TOMASI, 2011, p. 35). The comparison of Brazilian "political culture", understood as influenced by local parallel powers and structural corruption, with south Italy is usual. Also symptomatic is the comparison undertook by Judge MORO (2004, p. 6) from "Car Wash Operation" (Lava Jato) in Brazil with the "Mani Pulite" Operation in Italy, asserting that "structural conditions" for a similar "judiciary crusade against corruption” would also be given in Brazil.
} 
BETWEEN SCANDAL AND INVISIBILITY:

ad, were not only applied in relation to Brazil, but also to many countries of the so called "Third wave of democratization" (idem, p. 42f).

Apace with the political "historical" determinants of constitutionalism at play, stemming from the "Brazilian Sonderweg" - may it be reflected in institutions (here included the long-term effects of political Iberian ethos and slavery), in the normative body of the constitution itself or political culture, as seen above - other features were also analyzed as conditioning constitutionalism in the country. Among many, one can easily highlight socio-economical elements of the marginality, dependency and exploration theories of the 60ies and 70ies. But more importantly for our purposes is also the more contemporary "sociological" tendency to address the opposition of "constitutional normativity" VS “constitutional reality”, precisely if one understands the opposing poles not as amalgams, but as concretization processes (See Neves 1992, p. 56f, 2007a, p. 85f, 90f).

Setting the background for sociologically inspired analysis of the 1988 Brazilian constitutional context are not only political-cultural remnants maintained by the accommodating and epidermal traits in constitutional (quasi-)changes. Equally persistent in the debates, and considered as a "modern" product, is also the "fragmentation" and "dualization" of an unequal society in a "quasi-stratificatory" bifurcation of the population in sub-integrated and over-integrated strata; including their inclusion/ exclusion relations (access/dependency) towards the legal system (Neves 1992, 94f, 1994, 2006 p. $236 f$ and 246 f, 2007b). The effects of the so called "fragmentation" or "dualist, underclass/overclass society", as it is usually referred in other contexts and in the US debates (see, among many ARANTES, 2004), would also significantly influence the development or description of constitutionalism in Brazil. As categorically formulated by Telles: in Brazil, we would be faced with the "paradox" of a

[...] consolidated democracy, open to the formal recognition of social rights, civil guarantees and claimed citizenship prerogatives, but that must live with (and still must until the present day) the daily violence, violation of human rights and the incivility in the social relations (TELLES, 2006, p. 17).

Her approach is meant to reflect upon the possibilities and dilemmas of citizenship to root itself in Brazilian social practices, focusing on the plane of rights in the public scenario, i.e. as “practices, values and shared discourses” (TELLES, 2006 p. 137f). 


\subsection{Beyond Misplaced ideas - constitutive problematizations in Brazilian sociology}

Naturally, not all of the above selected different descriptions of Brazil are within the internal side of the "singularity" thesis, assuming that to understand Brazil one would have to deal with the burden of "the far away past that still surrounds us from every corner". If in the "Brazilian social thought" period "the singularity thesis" served as a "light house" to guide the political paths of the Nation to modernity and to foster national identity, it remains, albeit now in a greater level of reflection, present in sociological studies. One hopes to show only that the "specificity-theorem" in Brazil is not only one of opposing "(local) social realism" to "constitutional idealism”, nor was it only thought to be a "valorization of the center of modernity"; as if in our tropical Land ideas such as liberalism, democracy and constitutionalism could be nothing more than “displaced ideas". ${ }^{9}$ This is better understood as a background problematic that has irritated many different approaches - politically and theoretically and methodologically. There are so many and so varied standards and paradigms to explain Brazilian singularity as there are many and varied musters and paradigms to explain "the norm" of the European "normality” (no to say, that there isn't one all integrating European normality) - and the same applies to the critics of both generalizations.

Notwithstanding, going beyond the issues of the misplaced ideas and projects and projections of nation building and posterior theories of modernization, it is possible to gain another insight from the debate. Not a political, but an epistemological one (RIBEIRO, 2013). An underlying tension in these debates could be reformulated as the tension foreign/authentic, general/specific, rule-description/exception-description. This seems to be a constant not only in Brazilian social thought. MASCAREÑO and CHERNILO (2009, p. 85f) argue that the search for that, which makes Latin America simultaneously modern (universal) and Latin-American (particular), is also a characterizing feature of Latin-American sociology. Analyzing the tension between uni-

\footnotetext{
9 SCHWARZ, 2005, recognizes “displaced ideas” - i.e. political ideologies outside its original center in the European context - as a constitutive feature of the "Brazilian national character". It received many criticism, because it did not take into the analysis issues linked to the social structure of "Brazilian society". See VILLAS BÔAS FILHO (2009, esp. pp. 195 e ss.). For a reply explaining "misunderstandings”, see SCHWARZ (2012), and RICÚPERO (2008, pp. 64-65 e 68). The later highlights the element of tension between "form" and "environment" in Brazilian social thinking, stating that there were necessary "torsions" of borrowed forms that the periphery took from the center (see also NEVES, 2015, RIBEIRO, 2013).
} 
versalism and particularism, the authors address the issue of the ambivalent manner through which Latin-American sociology dealt with the modernity issue associating, on the one hand, its identity to national borders and its "immutable cultural ethos" and, on the other hand, adopting the more general and abstract sociological theories from various conjunctures, created and thought for diverse times and contexts. According to the authors, it is not to be argued in the sense of a total impossibility for the Latin-American sociology to consider its empirical specificities and to tackle the demands of "universally oriented knowledge of sociological canon", but to recognize that both a position that focuses only in particularism and an abstract and a-historical position that oversees the context are unattainable.

Moreover, this "comparison mode" of the singular path is not at all peculiar only to Brazilian debates. One could say, that this was also the case in other "famous-infamous" cases of "peculiarities debates", such as in Germany, alongside with the accompanying "dirty-laundering" national identity discussions, that in Brazil would, however, assume a feature of "upside-down narcissism” (STAM and SHOHAT, 2012, p. 184f). In Germany, the "explanatory" concept "Sonderweg” (singular or peculiar path) was used, sometimes positively (including apologetically in the Third Reich), and sometimes negatively, as in the more contemporary studies. The German debate was also one of comparison focusing developmental specificities, both culturally and in the academic literature, following heated debates. Also, political-cultural developmental traces where brought up to attribute singularities in shaping political culture, rights performance, constitutional design and specially (authoritarian) non-modern leadership conceptions. ${ }^{10}$

The use of the German concept "Sonderweg” regarding Brazil, as in the title of this topic, intends to point out not to the discussions of "explaining the singularities", or the problems of "essentializing culture", but to show that this mode of comparison is one present in sociology broadly considered and through manifold theoretical paradigms and variations. With CHERLILLO and MASCAREÑO (2009), it was shown above how the "specificity thesis" had also a productive side in sociological production of Brazil

10 For a critique of the all-explaining "German Sonderweg" and its substitution by a historic and communication media analysis on addressing "authoritarian leadership idealizations", see the compelling study from KOHLRAUSCH, 2005 , esp. p. $453 \mathrm{f}$ and $465 \mathrm{f}$. One should also add to the issue, that even when concerning the German Sonderweg, many have pointed out, that the very notion of "European norm" is one of difficult sustaining. Cultural studies and political “paths” studies usually oppose France, UK, Germany (and sometimes Scandinavia), affirming a heterogeneity instead of an European homogeneity - nevertheless often leaving aside Iberian Europe (Portugal and Spain), not to speak of eastern Europe. 
and Latin America. Nevertheless, regarding Brazil, if the "specificity thesis" would be excessively focused on the evidencing the "specificities of Brazilian reality" in a "sociology of inauthenticity", not reflecting adequately its relational comparison with the center of modernity (SOUZA, 2000, p 157f, 2006b - something that is debatable ${ }^{11}$ ), abroad (and maybe here more inadequately reflected), "Brazilian reality” was sociologically seen as a scandal.

\section{5 "Brazilianization of the West": Western Scandalization and the uses of "negative stereotyping" in sociology}

It was discussed above how the Sonderweg-topoi are used mainly to reinforce specificities and peculiarities usually focusing on the internal side of the difference. The socio-political singular developments in culture, history and institution-building are therefore placed in the center of the discussions, focusing on national identity building or institutional performance in explicit or implicit comparisons. Internally, if we use loosely a perspective from rhetoric, the Sonderweg-motif and topos is applied in comparison to unveil, attribute and reinforce the evidence of peculiarity, of rendering evident the "Brazilian (specific) reality". Its use was accentuated in the debates on the "political formation of Brazil" and its paths to "entering modernity", guiding "us" in the manner of "the light of a lighthouse" and in "imagining our nation".

Externally, so to speak, however, one could also find a rhetorical use of "Brazil", or more specifically, Brazilianization, as "shedding light” to rendering visible certain "social problems". It is true, that specially in a geo-political context of war and "overtly" performed violent racism from the 1930ies to the 1950ies, Brazil was thought to be a positive, quasi-utopian image to the West, being considered through European eyes as a possibility, in which a peaceful "racial democracy" and festive culture could be visible. Brazil was an image, as famously put by Stefan Zweig, of a "Land of the future" (see FN 6, above). Nevertheless, the "Brazilianization theorem" experienced its great boom and gained its proper label as a dystopian and dangerous imaginary in the discus-

11 For a good critique, in English, see STAM and SHOHAT, 2012, esp.p. $279 \mathrm{f}$. Not all of the criticized works by Souza blame "personalism" for inequality end up in a "liberal" ideology against the State. That is not at all the case in NEVES $(1992,1994,2007)$. Nevertheless, of course, one should not "accept the intellectual division of labor, that would reserve the labor of theory for the others [European or central -PHR] and leave us [Brazilian - PHR] with the task of "applying” them to our specific local peculiarities" (BRANDÃO, 2006, p. 77, also DOMINGUES, 2011). This is in no way proposed here when reaffirming the positive side of these tensions in sociology. 
BETWEEN SCANDAL AND INVISIBILITY:

sions on globalization around the earlier 90ies (BECK, 1998: 266f) Brazil became then a metonym for inequality and brought with itself a wide array of alongside characteristics, such as fragmentation, destruction of social integration or cohesiveness, social and urban disaggregation and violence, unrule of Law operating through informal networks, informal segregation in under-class and over-class polarization (see CUOCO, 2009, ARANTES, 2004, STAM and SHOHAT, 2012, p. 30f).

Brazil would have even achieved the status of a "sort of paradigm", a "sociological category for the black hole of globalization" ceasing to be "Land of the Future", and becoming the "modern spectrum" for the future of the civilized world (ARANTES, 2004, p. 30, my emphasis, STICHWEH, 2005, p. 56 uses the same black hole metaphor for “exclusion”). In Germany (BECK 2007, p. 28f), in the USA, (under-class/over-class studies) and France, one finds not only that the Favela is an epitome of exclusion, but Brazil itself is metonymically used as exempla and metaphor of fragmentation and extreme inequality (see STAM and SHOHAT, 2012 p. 30, also the critiques from NEVES, 2006, p. 149 and 2007a, 191).

This mode of comparison is clear in the reflections of Ulrich Beck on the "Brazilianization theorem" (BECK, 1988, p. 262f). Beck considers Brazilianization of the West to be an "unwanted consequence of the neoliberal utopia of free market", where the "patchwork carpet" of precarity, multi-activity structure of work ("feminization"), confusion, minority of formal work and insecurity of forms of work and life that are typical of the South spread to the center (BECK, 2007, p. 28). Here "Brazilianization" is conceived as a possible "mirror image", a "glimpse" into the future of the insecure world of work in the West, reflecting a gray zone between work and no-work, informal and formal employment, where no full employment is conceivable (BECK, 2007, p. 127f).

Beck admits that the "theorem" incurs in stereotyping and must face the many problems of "cultural comparison", but goes on to reinforce this use as an "exacerbation" (Zuspitzung), as a "negative cliché" (Negativschablone) to be useful for the deconstruction of western values and developmental ideas, showing the "disorder of progress". This could help Europe to look upon these Lands and their development to address how say farewell to full-employment, seeing beyond "the scandalous category of unemployment" (idem, 138f, emphasis added).

One could also argue, as Neves (2007, p. 197) ironically indicates on the issue of "peripherization of the center", that the "Brazilianization theorem" is nothing more 
than the perception of the global dimension of poverty and exclusion in the so called "centers" of the world society. The "discovery" of exclusion, fragmentation, polarization and destruction of the "social ambiance" of fundamental rights "in Brazil", labeling the danger of its spread as a Brazilianization of the world, is a part of the perception that exclusion is not to be understood only by national methodology or as a regional problem, but is a very constitutive issue for the world society. The metaphors of visibility and the use of the rhetoric of the scandal are very present in these debates. To show it, one could retrace "Luhmann's discovery of inequality in Brazil” (item 2) and the sociological analyst of human rights scandals (item 3).

\section{Luhmann and the "discovery" of inequality in the tropics: inclusion/exclusion revisited}

Luhmann proceeded, after the early 1990ies, to review and change his concepts of inclusion and exclusion. Even if before the 1990ies, the concept of inclusion was already described as not a clear-cut one(FARZIN, 2008, p. 191f, BACHUR, 2012 p. 56f, 76f). The theoretical and methodological "shift" addressing the problematic was, nevertheless, unequivocally pointed out - regardless of being received critically or appraisingly. ${ }^{12}$ More importantly, one meaning adopted by the author's concept in the period - one could call it "factual exclusion(/inclusion)" - could correspond precisely to a theoretical "functional equivalent" to the question of inequality and generalized "social exclusion". In the works by the later Luhmann Both the "factual" and "evident" relevance of exclusion in peripheral contexts (or "sectors of exclusion" LUHMANN, 1995c) are made clear by the statement of Markus SCHOER(2010, p. 298), that a possible reconciliation between the social inequality theories (Ungleichheitstheorien) and the functional differentiation theories seemed to have failed: "at least that is what it looked like until Luhmann returned from his travel to Brazil". ${ }^{13}$ More importantly, as KRONAUER (2010, p. 122f) states, not only much had already been written before Luhmann's “discovery”

12 Sina FARZIN (2006, p. 11 and 49f) argues that, in his later works, after paying attention to "massive misery (Elend)" in modern society, Luhmann understood exclusion as a counter concept to functional differentiation FARZIN (2012, p. 88). She recognizes further that the theme "inclusion/exclusion" began only in the early 90ies to question, inside Luhmann's theory, the primacy of functional differentiation. See also LUHMANN (1995c), BALKE(2002), NASSEHI (2012, pp. 404-405).

13 Such statement should be read cum grano salis. A broad "reconciliation", with same ground discussions, does not seem to have taken foot. See; SCHWINN, 1998; KONAUER, 2010 NASSEHI, 2012, p. 404. See also, the references in BACHUR, 2012 and the work of Roberto Dutra Torres Junior - DUTRA 2012 and 2013. 
of poverty and inequality in the 90ies, but "Luhmann's unsettling encounter with the poverty in the favelas resulted [also] in a tremblor (Erschütterung) in the foundations of system's theory", something that required revisions and new discussions.

Similar conclusions are often supported by reference to the author's texts in this period, ${ }^{14}$ many of them reporting through a heavily laden metaphorical discourse, the shocking view of the "reality beyond description" of his visits to the favelas (LUHMANN, 1999, p. 244 - albeit formulated in hypothesis and in indefinite personal pronoun). Beyond this semi-biographical explanation, however, one could note that, as early as 1992, Luhmann actively responded to critiques that his theory would suffer from a "empirical provincialism" (NEVES, 1992, p. 9; see also 2004, p. 167) and would be, therefore, inadequate to explain the sectors/regions of world society where exclusion and inequality could render problems of generalization to the functional differentiation theorem and system autonomy, at least if taken unquestionably (on Neves' case, considering especially the legal system and constitutional concretization). This counter can be found in the preface wrote by Luhmann in Neves (1992):

[...] Maybe the realization of functional differentiation on the level of world society, with high internal dynamic of economy, science, mass communication system, politics, etc., may not imply, for long, that the corresponding conditions can concretize themselves also in the regional plane. Maybe there are, in-between, indicators of a pre-ordained, primordial difference that regulates the access to advantages of functional differentiation, i.e., the difference inclusion/ exclusion. [...] This would mean that society in Brazil is integrated in a twofold manner: positively, through networks of favors, gratitude, patron/client relations, corruption, and negatively through the practical exclusion of many from the participation in all functional systems - a situation in which one exclusion (lack of papers and legal documents, of work, of regular nutrition, of education, of health insurance, of security concerning body and life) unquestionably brings with itself, more and more, other exclusions.It is to be expected that the work of Marcelo Neves should be read not as a set of information on exotic legal relations in a country belonging to the peripheral modernity, but mainly as to stimulate the thinking on the society in which we live today (LUHMANN, 1992b, pp. 3-4).

\footnotetext{
14 See, e.g., LUHMANN, 1993a, pp. 580 ff.; 1995c; 1999; 1998; 2000a, pp. 247 ff.; and 1997, esp.p 618f, p. 632f, many of them referring directly to NEVES, 1992.
} 
In this same preface, Luhmann states that the opposition of "constitutional reality and constitutional normativity" assumes a different depth in Brazil as in Europe (1992, p. 1; NEVES 1992, p. 56f, 2007a, p. 85f.). Here one can see Luhmann tackling issues that permeate the Brazilian and Latin-American debates in social sciences (item 1.3). More importantly, one finds here not only a great deal of his latter developed arguments and thesis in embryotic form (see references in FN 14, above), but also the author's interest in facing these critiques in the fashion of further developing his "super theory" (LUHMANN, 1984a, 9f) in abstract manner, expressively rejecting singular or externalizing explanations of "exotic legal relations" and pleading for a general, all-encompassing theory framing of the debate. Furthermore, one could note that the author alludes to "facts described", opting for a formulation heavily laden with references to "reality".

In 1993, albeit reinforcing and maintaining the general concept, Luhmann recognizes then a "asymmetry" in the world society and that "there is a strong difference between inclusion and exclusion that, while it is produced by functional differentiation, is incompatible with it and ultimately undermines it" (1993a, p. 582). He concludes that, in such environments, "probably the best approach would be to use the hypothesis that the difference between inclusion and exclusion functions as a sort of meta-code, which mediates all other codes" (see, LUHMANN, 1993a, p. 583 and 1995c). ${ }^{15}$

Furthermore, Luhmann partially followed the thesis of Marcelo Neves (1992) that, in such situations, a legal system is no doubt functioning mainly by the difference lawful/lawless (Recht-Unrecht). However, such difference would have belittled relevance for both the excluded (under-integrated or under-included) and over-included population groups. Both sides could "opt" (or "be forced to") either to act accordingly to the Law, or not accordingly. The legal code and its programs would then function in a frail way, since other preferences - such as those of economy, for instance - would take prevalence. That would have such an impact that could lead to a generalization of expectations, considering that it would be expected that even the politics and the police might not act mainly through the legal difference (LUHMANN, 1993a, pp 583f; NEVES 1992, p. 203f).

15 For some critiques, see NEVES (2006, pp. 251-252), and NASSEHI (2012, p. 404). Beside internal consistence problems, NASSEHI warns against a "fascination with the exotic" 2004, p. 323f). RODRIGUEZ (2010, p. 44), warns against the danger of ontologizing the explanation by marginalization, and states that excluded parts of the population are in fact not integrated, but cannot be conceptualized as ontologically marginalized. 
BETWEEN SCANDAL AND INVISIBILITY:

Luhmann goes far enough to assume a pessimistic vision on possibilities "of generalization, to the world society, of some welfare standards of living found in developed countries” (2005, p. 80f):

[...], it may very well be that the current prominence of the legal system and the dependence of society itself and of most of its functional systems on a functioning legal coding are nothing more but an European anomaly, which might level off with the evolution of global society (LUHMANN 1993a, p. 585-586).

Luhmann then (re)addresses issues of social integration, understanding it as the other side of the difference differentiation/integration. In other words, to address the issue of "(inclusion)/exclusion", he considered necessary to undertake a broadening and a complementation of the social differentiation theory, "dominant in sociology since the classics". To face this problem, he proposes one "to substitute the theme of social integration by the distinction inclusion/exclusion" (LUHMANN, 1997, p. 619). He further correlates the difference inclusion/exclusion, could be related to "typical situations" that are "more visible in contexts of peripheral modernity", but does so in order to address "structural problems of the functional differentiated society" (1995c, pp. 226-227; 231-232 emphasis added).

Luhmann defines society's integration as the "limitation of freedom degrees that the structurally coupled systems provide to each other reciprocally” (LUHMANN, 1995c, pp. 227; 1993a p. 584). Therefore, the author departs himself from "positive theories" of social integration that rely themselves in concepts of integration through values or moral consensus (e.g. Durkheim or Parsons) and that work within a developmental logic towards full inclusion. For Luhmann, social exclusion is to be faced as a “logic shadow", let invisible to sociological debate (1995c, p. 244).

He states, moreover, that seen through the perspective of the centers of modernity, such peripheral contexts could seem to be the result of a "failed modernization". However, Luhmann rejects "modernization theories" and engages in what he calls a "more accurate explication" of "modern exclusion modes" in recognizing that society would be more intensely integrated in "exclusion sectors", something more visible in peripheral contexts, but what, in the end, would result in the immobilization of politics, economy, law, social mobility and even of the academic system (LUHMANN, 1995c, p. 240). 
In contexts of exclusion, however, society's integration turns out to be extremely more intense: exclusion generates exclusion resulting in an "exclusion spiral", because the exclusion from one functional system implies the exclusion from a great deal of others. That becomes something dramatic when one considers that functional systems have only capacity to control inclusion internally and that, the greater the exclusion, the lower the capacity of systemic inclusion in other functional systems (LUHMANN, 1995 c, p. 148, 1997, p. 630).

One must further note that the inclusion/exclusion concept in Luhmann's sociology does not restrain itself to thelegal and political scope of regions such as Latin America. The author applies this concept to the "regional level" (1997, p. 806 f), but also to "exclusion sectors", which are to be found inside developed countries, as the example of the American "ghettos", industrial neighborhoods in Wales and other similar structures to be found in any big city worldwide. Even admitting that every sector of exclusion can have their own historical and empirical specificities, Luhmann argues to be possible to access, by means of his theory of society, their "common structures" or equifinal (Äquifinal) effects (LUHMANN1995c, p. 243). In these sectors, the difference inclusion/exclusion would function as a meta-code and persons would count as mere bodies, separated and agglomerated, in a context in which all that we conceive as a person retrocedes (1995b,1995c, p. 245). In the ambit of exclusion, the communication media would lose their specific meaning and physical violence, short term basic needs would rule (1997, p. $631 \mathrm{f}$ ).

Luhmann acknowledges that such extreme exclusion situations are not empirically clear or given, and that there is always some degree of inclusion. This is however used as e limit case in his argumentation (1995c, p. 246). And, here, "Brazil" and the favelas are seen through Luhmann's eyes (and not through Luhmann's "theoretical lenses"!) as both the metonym and the confirmation of this "limit case". Here it is symptomatic, as we saw, that Luhmann uses the light and visual metaphor of immediacy (directedness) of the human eye and the physical presence of an anthropomorphic observer, whose "body" was there at the sight. It contrasts sharply with his other works and style that highlighted abstraction, mediacy (inaccessibility, indirectedness) and perspective (second order cybernetic). ${ }^{16}$

16 For the positive use of "visual metaphors" (such as observation, perspective) by Luhmann, and a negative use of sound metaphors (such as noise), see the compelling argument from STÄHELI, 2007 and the considerations of LÜDEMANN, 2004, p. 15f. The metaphor of the “eye” (Luhmann's eye visiting the favelas and walking through the streets of Brazil) "describing the indescribable" of the "reality of exclusion" is starkly different from the "abstract lenses" of his "highly complex" theory of society. See the arguments "of Latin American scholars that analyze the world through Luhmann's lenses" ("Durch Luhmanns Brille”), BIRLE, et al., (2012, p.10) 
What is to be highlighted for our purposes is that Luhmann ends up considering the functional differentiation theory as too simple to explain society, being in need to be "enriched" by new theoretical displacements that, in last analysis, would imply to abandon the hope that differentiation society could be described sufficiently well under the perspective of a typical predominant differentiation, stratificatory or functional (1995c, 246), even if the functional differentiation is maintained as an important principle of theory and as dominant in world society (LUHMANN, 1995c, p. 243-244, for an analysis of further discussions BACHMANN, 2016).

His way of addressing this issue, i.e. in an anthropomorphic, metaphorical and evidence-rendering rhetoric, is the main point of this essay. Such as in the following passages:

This points out to the conclusion that in exclusion sectors, people (Menschen) are apprehended as bodies (Körper). When, for instance, one visits Brazil's big cities, and moves through its streets, squares and beaches, it demands an indispensable social competence of a constant observation of positioning, distancing and gathering of human bodies. One can feel one's body more than usual, one lives more than usual inside of it. [...] There is much more of a form from intuition-driven perception, that contributes for the perception of dangers and for their avoidance. And conversely, naturally, foreigners and other objects of attack are also identified as bodies. All of that, that we would apprehend as a person falls back, and, with that, also all the attempts to achieve social effects by influencing attitudes. That would require a context of social control and social community (soziale Gemeinsamkeit) that, in this case, cannot be presupposed (1995c, p. 245, emphasis added). ${ }^{17}$

Further, in Jenseits von Barberei, Luhmann sustains that the modern mode of exclusion is singular and that "stratification becomes only a byproduct of functional systems, specially the economic and educational ones” (LUHMANN 1999, p. 141). He then manifestly questions the primacy of functional differentiation of modern society as follows:

17 Luhmann goes on, on the footnote, to address the "new forms" of sociality and rapidness of adjusting to "occasions", comparing it with the popularity of soccer and to the promptness to violence, risk for life and bodily integrity, mentioning the spread of AIDS (!) in Brazil (1995c, 245-246). See also 2000b, p. 89-90, where Luhmann compares soccer with the fascination of "lightness and weightiness", quoting, in Italian, the leggerezza/pesantezza of the world - and soccer as its symbolization. He compares the rise of Nationalism in soccer Stadia as counter weights or "heavy ties" reactions to counter the "lightness" of abstract globalized impersonal functional systems. 
To the surprise of the well-meaning it must be ascertained that exclusion still exists, and it exists on such a massive scale and in such forms of misery that are beyond description. Anybody who dares a visit to the favelas of South American cities and escapes alive can talk about this. But even a visit to the settlements that were left behind after the closing of the coal mines in Wales can assure one of it.

To this effect, no empirical research is needed. Whoever trusts his eyes can see it, and can see it so impressively that all explanations at hand will fail. We know: there is talk of exploitation, of social domination, of marginalidad, of an increase of the contradiction between center and periphery. But all these are theories that are still governed by the desire for all-inclusion and therefore are looking for addressees to blame [...]. But if one takes a closer look, one does not find anything that could be exploited or suppressed. One finds existences reduced to the bodily in their self-perception and other-perception, attempting to get to the next day. To survive, they have to develop abilities of perceiving dangers and of making available what is most needed - or resignation and indifference with regard to all "bourgeois" values: including order, cleanliness, and self-respect. And if one adds up what one sees one can conceive of the idea that this may be the guiding difference of the next century: inclusion and exclusion (1999, p. 147. Emphasis added).

Luhmann uses Brazil('s favelas) as a metonym for his limit case and questions himself about the consequences for the social systems, including the legal system, questioning even how exclusion could render difficult the concretization of the State based in Law (Rechtsstaat) and the action of the police (1995c, p. 243-244).

On his early studies on fundamental rights(1965), Luhmann had already formulated broad social "presuppositions" for the concretization and generalization of fundamental rights in its function of maintaining functional differentiation - something he latter sustains that cannot be presupposed in exclusion sectors (LUHMANN, 1992b, p. 4). But he did so at the time (1965) still mainly relying on a "civilizational" perspective and only regarding the expansion of the political system (JAPP, 2015). ${ }^{18}$ Klaus Japp draws attention to the fact that Luhmann uses a "certain degree" of "institutionalization of generalization of behavior expectation" and points out the deficits of this in "underdeveloped countries or regions"; considering "civilization" to be a "promptness to orient oneself by

\footnotetext{
18 For fundamental and human rights' function as countering expansionist tendencies of all systems, TEUBNER, 2012, Ch. 4
} 
indirect abstract (consequently, generalized) expectations” (LUHMANN, 1965, p. 96). Where this was lacking, the State could not enforce it. Needed was also family (as preparation for civilizational learning) and the "civilization of behavioral expectations" (“Zivilisierung der Erwartungen” - LUHMANN, 1965, p. 86, 106, JAPP, 2015).

Japp argues how Luhmann's analysis in 1965 were mainly centered in a nationalistic approach, and how only after the 90ies Luhmann would have referred to the world society and human rights more properly, even if the distinction of functions from both are still difficult. Japp considers that Luhmann, in 1965, had made a difference between highly developed lands, with “civilized expectations" - i.e. high generalization of expectations, and therefore being capable of complex communication - and underdeveloped ones, which had only "weak" possibilities of generalizing expectations. Japp's point is that the difference "uncivilized/civilized" (not-generalized/generalized expectational structures) was latter (1993a) substituted by the difference inclusion/ exclusion and "regions/world society". He follows to develop a critique of the "liberal" conception of human rights in the world society (JAPP 2015, p. 65f). In fact, in this early study, Luhmann intends to develop a sociological study that focuses on the variability, contingency and functions of the so called inviolable values of legal dogmatic and value theory (LUHMANN, 1965, p. 8). When dismissing the theories of legal sources (Rechtsquelle)(idem, p. 28f) and value theories (p. 204, 213f), he classifies fundamental rights as "institution" (idem, p. 12-13), i.e. as a complex from factual behavior expectations, that are generalized temporally, materially and socially.

The function of fundamental rights is not to be understood, sociologically, as the differentiation between State and society, or even as protection of the individual against the State. For Luhmann it meant the maintenance of functional differentiation, i.e. a protection against de-differentiation of the social system (idem, p. 27), specially against the expansionism of the political system (idem, p. 96f).

The point, here, is that Luhmann sustains that there are some historically developed "presuppositions", which are understood as increased availability of communication and, accordingly, increased self-discipline that comprise the fundamental behavioral aspects of the general process of civilizational differentiation" (idem, p. 22 - referring to Norbert Elias) for the State to function, that must to be found in its "ambiance" -i.e. the functioning of statehood and fundamental rights depends on the possibility to link itself to civilizational presuppositions of its ambiance (idem, p. 85-86). Fundamental rights' function is to maintain these and avoid de-differentiation. These consider- 
ations show also relevant differences of the young and the latter Luhmann in addressing exclusion, inequality and "underdevelopment”.

\subsection{Discussion: "Brazilian reality" and the "impressive seeing" of the two dark sides of functional differentiation}

The above considerations should suffice to show how the latter considerations of Luhmann on inclusion/exclusion influenced the author's thinking in the 90ies and set forward a heated debate among commentators. Moreover, it is also clear, that studies of Latin American legal sociology played a key role in these theoretical "displacements”. In this case it seems that the "themes and problems" so central to Brazilian (legal) sociology and social sciences that informed Latin American students from Luhmann ${ }^{19}$ and the following discussions, is what mainly set this theoretical movement in motion. And not only the "impressive seeing" of Luhmann's "direct observation" that happened shortly after his first contacts with the thematic. Therefore, neither only biographical elements of Luhmann's visits to Brazil are to be held responsible, as SCHOER (2010, p. 298) argues, ${ }^{20}$ nor as it appears in the above-mentioned passages, where one encounters the old narrative of the (European) "adventurous scientist-traveler" reporting on (passive and mute) exotic scenarios - so exotic that no theoretical lenses, but only naked (European?) eyes would be necessary. ${ }^{21}$ It is however symptomatic that Luhmann fell into "impressionist descriptions" and into a rhetoric of "describing the indescribable reality of exclusion", without confronting thoughtfully neither the traditional German "Ungleichheitstheorien", nor the studies of Brazilian and Brazilianist sociology on the matter. Nevertheless, the author took matters and critiques in a serious manner, and proceeded to undertake developments and changes in his theory (RIBEIRO, 2013).

19 For Luhmann's reception in Latin America, NAFFARATE and MANSILLA, 2006. On prefacing the work of the Brazilian Sociologist Claudio Souto, Luhmann references "Brazilian sociological tradition", but as a different approach on dealing with theory. He then compliments Souto's "sociologic reduction" and abstraction in his theory, something that seemed also to be a critique addressed to "sociological traditionalism" in Germany (LUHMANN, 1984b).

20 Luhmann himself, in his usual ironical fashion, stated that the need to rely on biographical explanations to understand a theory would imply either the lack of consistence and autonomy within the theory itself, or the lack of adequate understanding by the reader (LUHMANN, 1987b, p. 19).

21 For a post-colonial critique of Luhmann's human observations of the global south in his later work, comparing it to the black hole metaphor and the novel "The Heart of Darkness", "in an imperial rhetoric of colonial travel writing", see ECKSTEIN and REINFANDT, 2017. 
BETWEEN SCANDAL AND INVISIBILITY:

It is even more symptomatic to note how a theory that refutes all kind of "national methodologies", “concrete regional or national examples” and "reliance on direct observations of a anthropomorphic individual on social reality", falls into "sociological impressionism”, “dense imagery”, "concrete exemplification of case descriptions" ("the streets of Brazil”, "Brazil's favelas”) and strong metaphoric (see the leading study of FARZIN, 2008, sp. p. 191f and 2006, STÄHELI, 2007, ECKSTEIN and REINFANDT, 2017, to name a few). These correspond precisely to some of the obstacles epistemologiques, i.e. epistemological blockages, that Luhmann argues to be the obstacles for an "adequate" theory of society (LUHMANN, 1997, p. 24-25).

It is not, however, the main point of this essay to criticize this approach as Eurocentric or to fall once again into "national identity issues", but to try to make this debate a more fruitful one. A way to do that is to focus on epistemological issues. This essay intends to show how some comparison modi of Brazil in(legal) sociology are organized, tracing paths that point out to both limitations and possibilities of its use.

Therefore, one does not need to praise the "first observations" and the shock of the "first encounters" with diverse cultures, as it seems to be the case in the comparison of the latter Luhmann with the anthropologist Claude Levy-Strauss (both referring to Brazil), inferred in the argumentation of BALKE (2002, p. 33f). On the other hand, maybe instead of condemning without further argumentation the use of metaphors in theoretical sociology, one could face it seriously as a constituting trace of theoretical argumentation.

In this sense, if it is true that "a theory must open possibilities of comparison" (LUHMANN, 1984a, p. 7), one must note that there are many ways to do so sociologically. While Luhmann focuses on "functional analysis" (1984a, p.83f), there are many other available in sociology, as e.g. ideal types (Weber), national methodology, symbolic interactionism, institutionalism and so forth. One way to do so is also by "negative stereotyping of the other" (BECK, 2007), in order to highlight some certain characteristics of a given observer contrasting with stereotyping of the observed; or - even more immersed in visual metaphoric - by "contrast foiling” (Kontrastfolie - SCHEIDER, 2011), where the example is set precisely in order to set a certain background to highlight or "contrast" something in the foreground. Both strategies abound in sociological studies relating to Brazil. This effect can also achievable by rhetorical devices such as metaphors and evidence-rendering, reality-unveiling rhetoric; to be found both in " $v i$ sual metaphors" and “scandal rhetoric". Specially if a metaphor, if not a concept, follows 
the structure of "asymmetric antithetical concepts" (KOSELLECK, 1992), and draws a distinction in which the outside (unmarked space) is characterized by the absence of the elements of the inner side. The concept of darkness, for instance, is precisely defined by the absence of light - the latter being the medium of vision, i.e. the prime human perception modus of "directly" accessing the reality in the environment.

As stated in the introduction, this essay follows loosely the "metaphorology", in its search for themes and elements in the "substructure of thought". In the first part, in the traditions of "Brazilian social thinking", Sonderweg-topoi and "Brazilianization of the West", one finds an abundance of light and visual metaphors, usually functioning as evidence-rendering arguments and narratives. Brazilian social and political institutions, including and especially the legal ones, would drift amidst a "curious twilight" and a dangerous "gray zone"; permeated by, on the one hand, "invisible" or "dark" social forces (informal, environmental, singular, cultural, local, personal, patrimonial, elitist, racist, inequality ascribing), and, on the other hand, "visible" and "enlightened" ones (formal, systemic, civilizational, general, universal, global, impersonal, liberal, egalitarian, democratic, bureaucratic). Of course, there were and still are manifold critiques - alongside many normative and descriptive disputes on the matter and on its usage or interpretation -, that cannot be addressed here. Nonetheless, whereas for the early debates sociology and social thought were seen as the "lighthouse" that could shed light to unveil the "Brazilian reality" and enlighten the way to its overcoming, the same "Brazilian reality" was perceived by foreign sociologists as the epitome of "the black hole of globalization", exponentially engulfing all the "light" of "global progress" and jeopardizing functional differentiation.

As metonym for exclusion and endangerment to the lights of functional differentiation or modernity (of "the West"), Brazil and its reality would evidence that "the face of modernity is a landscape of light and shadows" (BRUNKHORST, 2005, p. 113). ${ }^{22}$ The same "reality" (with its effects on the legal real and its "ambiance" includ-

22 This metaphor is also attributed to progress and "imaginations of all-inclusion" (for a critique, LUHMANN, 1995c). The Enlightenment (Aufklärung) itself is already a common-sense concept that is the epitome of this relation (see, further, SCHALK, 1971). For a harsh and polemic critique, not only with metaphorical word play, but with legal historiography on the slavery transatlantic codifications of French colonies - Code Noir - and the exclusion of black people of Enlightenment in texts of its prominent thinkers, see SALIN-MOLIN, respectively 1987 and 2006. Luhmann himself theorized upon the tense relations on Enlightenment and sociology, including the idea that the Aufklärung would enlighten the "occult", the "secreted" and the "latent". Albeit not completely dismissing the notions of self-reflectiveness and autonomy, he positions the task of sociology as to displace the naive notions of human individual and essentialist reason alongside a safe assumption of a better society moving towards a sociological theory that could better grasp the multi-causal and contingent elements of "the social". He proposes, therefore, in a world game immerse in light metaphoric, a "sociological clearing of the Enlightenment" 
ed) is therefore used for shock value and to set a contrast foil to discuss the perils faced by Europe and the USA ("Brazilianization”).

Incidentally, one finds the same metaphoric frame in the (quasi) normative interpretation of the presuppositions of functional differentiation, especially to be found in system's theory inspired legal sociology. Here one highlights the importance of guaranteeing and maintaining functional differentiation, a function specially but not exclusively exerted by the legal system(s) and fundamental rights LUHMANN (1965) attributes this (latter: "immunological" - 1984, Ch. 9) function to fundamental rights against the political system, TEUBNER (2012) to societal constitutions (and human rights) against expansionist tendencies of all social systems, with NEVES(2013, p. 174f) doing so while warning against the regional asymmetries, alongside the deleterious effects of generalized exclusion and inequality on the legal system and constitutional efficacy, being inclusion an "empirical conditioning, a functional requirement and a normative claim" of modernity. Moreover, functional differentiation sometimes assumes almost a metaphorical character of "light", endangered by the "de-differentiation" - i.e. its negative side (see the critique of BACHUR, 2012). The problems of functional differentiation are correspondently sometimes described almost in literary fashion: the endangerment by the "black holes" of exclusion (STICHWEH, 2005); the shadows in the landscape of (functionally differentiated) modernity (BRUNKHORST, 2005), and the fragmentation and "compulsions of expansion" of all systems as "the dark side of functional differentiation" (TEUBNER, 2011, 2012 Ch. 4, STICHWEH, 2011), rendering exclusion a "logical shadow" of difficult understanding by sociology (LUHMANN, 1995c).

The system's theory inspired legal sociology must then face the perils of the limitations of this dualistic, metaphorical underpinning of the primate of functional differentiation. As seen in the item above, Luhmann redefines the "other side" of functional differentiation departing, firstly, from the difference "differentiation/integration", with its problems of fragmentation and "compulsive expansion tendencies of social system's rationalities". He then proceeded towards substituting “integration" for another difference: inclusion/exclusion. Here he poses the problems of the functional-differentiation-undermining generalization of exclusion. One notes that, by doing so, Luhmann left two open flanks to be defined as "the dark side" of functional differentiation: fragmentation and generalized exclusion. 
One could argue that two system's theory inspired legal sociologists developed their work specially centered in one of these two "dark sides of functional differentiation”, gravitating around the two flanks left open by Luhmann. Even if both authors recognize and address both problems, whereas Gunther TEUBNER (see, among many, 2012, Ch. 4) emphasizes, from the legal-sociological perspective of his "soziologische Jurisprudenz," the problem of fragmentation and systems' rationality collisions, Marcelo NEVES (among many 1992, 1994, 2013) emphasizes, from the constitutional and legal-sociological perspective, the problem of generalization of exclusion and asymmetries both in the world society and among "legal forms".

The main point is that both attributed "dangers" of de-differentiation are maintained (and not actually substituted) in Luhmann's theory. On this aporetic formulation of "two dark sides", one encounters the limitations of a dualist light-darkness metaphorical "substructure of system's theory thinking” of inclusion-exclusion, that, albeit not undermining the theory, points out to some theoretical unclearness and unresolved problems. ${ }^{23}$

What does one take then from this posing of the debate? On the specific issue of Luhmann's "encounter" with social exclusion and "Brazilian reality", one notes the use of a narrative mode of concreteness (e.g. reduction to mere bodies), that "shows and unveils" a crude reality, that is factual and accessible to the naked eye. The issue of "generalized exclusion" is then described as being paradoxically easily perceived, promptly grasped, but nevertheless "indescribable". The same "reality", visible to the naked eye, is said to be invisible to sociology (i.e. "logical shadow"). Further, it is invisible both to local interaction systems ("invisibility of inequality") and to social systems ("exclusion spiral"), but shockingly and "impressively" visible in the bodies on the streets of Brazilian big cities. Maybe, in the effort of overcoming integration and consensus theories in sociology (e.g. Durkheim, Parsons), Luhmann's theory still faces some difficulties in theorizing the other side of differentiation by means of its differential theory (differenztheoretisch). This is even implicitly admitted by a "rhetoric of invisibility and visibility" (FARZIN, 2008) alongside one of "inconceptuability" und "indescribability" of social exclusion(LUHMANN, 1995c,

\footnotetext{
23 In a more detained approach, one can see that the general scope of Luhmann's theory, especially in its branch of social evolution theory, does not conceptualize functional differentiation as a teleologic stage, being therefore contingent and possible to disappear or loose primacy in the evolution of society. Media theory inspired "Luhmannians" even hypothesize on the emergence of new differentiation modi in "the next society" of the new digital communication media, as in BAECKER, 2007.
} 
1999). Not by chance, BLUMMENBERG's study (2007, "theory of inconceptuability” Theorie der Unbegrifflichkeit) places the metaphorical precisely there, where we could say that thought systems face their limitation and "inconceptualizations".

It is true that this confrontation of the latter Luhmann with social exclusion have led to positive debates, besides notable developments and reviewing of his theory. Further, it is also true that his texts on inclusion-exclusion, and the manifold debate on the matter, cannot always be reduced to this dualistic metaphoric. Nevertheless, one still faces problematic passages that fall back into it. One of the main problem is the difficulty of theorizing exclusion beyond a a-functional, negative understanding (see BACHUR, 2012). Albeit his development on inclusion-exclusion networks (LUHMANN $1995 \mathrm{c})$, the theory still faces difficulties in understanding the "gray areas" between the two poles, resulting in conceiving exclusion as only “surplus”, (1999, 1997, p. 631f, 1995c) or, as formulated by other traditions, as "abject, a-functionality, left overs, excrescence". Exclusion is understood only in its limit case. It was already argued that, on the issue of social exclusion, system's theory faces the limits of its own descriptions capacities and position exclusion as a reality almost "beyond society" itself (OPITZ, 2008, p. 190, and FARZIN, 2008, p. 195, where she argues that one faces the limits of the theory and a suggestion of a "reality beyond social systems"). It is then understood as the limit of society itself, where not even persons, but only bodies are to be found in this internalized outside of a world society with no outside, i.e., that is "beyond barbarism” (LUHMANN 1999, somewhat echoing Agamben's “naked life”). In the enlightened world (society) of functional differentiation, there would be no place (and not even no available description!) for the "excreted non-world" (i-mundo) of exclusion, if not only the shock and the scandal of its recognition. ${ }^{24}$

One hopes to show, in the way of FARZIN (2008, p.196), that this metaphoric of exclusion is not only to be addressed as theoretical deficits or logical contradictions. They have also a potential to induce "productive irritation”. Even if Luhmann's considerations on the matter are to be, at the end, considered insufficient, the contact with the uses and traditions of Brazilian social and legal "reality" as a characterizing

24 For the world play of "mundo" (world) and im-mundo (both meaning "non-world" or "a-world" and "filth(y)" or "trash"), see, on the matter of Brazilianization as proliferation of the im-mundo qua social fragmentation, spatial segregation and state of exception, CUOCCO. 2009, p. 54, 225f. For the metaphor of "trash" in exclusion rhetoric, rendering drastic and dramatic topoi of marginalized as excluded/expelled from modernity, see, FARZIN, 2008, p. 196, also her comparison from Luhmann's warning against the "contagion of exclusion" with an epidemiological metaphor of illness (p. 193). 
field-issue in legal sociology was also sproductive. Here, the Latin American social "ambiance" of fundamental rights in situations of social fragmentations and generalized exclusion influenced the author. One could say that it is a part of a potentially "productive misunderstanding", helping the debates and theoretical developments, even if by questionable "negative stereotyping" (BECK, 2007) or "contrast foiling” (SCHNEIDER, 2015), to develop critiques on generalizing theories. This seemed to be the case by Luhmann's theorization on exclusion and asymmetries on world society.

However, Luhmann's “inclusion-exclusion” passages are not the only passages where one finds this quasi literary rhetoric of "showing reality" (auf die Wirklichkeit zeigen) in his works - i.e. something that leads "to a referencing to the undoubtable real and its adequate reaction, both in cognitive as in normative sense" (KOSCHORCKE, 2015, p. 14-15). This rhetorical drive is also present in his linking of the validity justification (Geltungsbegründung) of human rights with public outrage unleashed by scandals of human rights' violations. ${ }^{25}$

In a different way, scandals (of human rights violations) are also prone to this "impressive seeing" that Luhmann talked about, and also render the "real" "visible and experienceable" (KOHLRAUSCH, 457 - for the linking of scandals with "transformations of visibility” see THOMPSON, 2000 p. 33f). But, following what was discussed above, this "impressive seeing" is not always productive on the plane of the theory. More productive would be to "to look for practices of knowledge", as stated in LETHEN (2015, p. 10f), and to question how the "effect of the real" is produced socially - i.e. how social communications make the invisible visible (for the art, Luhmann, 1990, p. 14).

\section{On scandals as validity justification of human rights (and its limitations)}

One incisive thesis from Luhmann concerning human rights, among many other, is that scandals of human rights violations are to be understood, paradoxically, as being the validity justification (Geltungsbegründung) of human rights (1993a, p. 574f; 1995b p. 222). Even though one considers this thesis to be generally correct, it usually leaves aside the social and historical "conditions of possibility" (Bedingungen der Möglichkeit)

25 I thank here the discussions of this hypothesis of mine with Prof. Neils Werber. 
that are necessarily present in scandalization processes connected to "universalist claims in the form of rights". ${ }^{26}$

Considering it as one of the most meaningful indicators of a world society's legal system (1993a, p. 574), Luhmann states that

One can observe nowadays an increasing attention for problems of human rights violations [...] What one can observe is a very elemental (ürsprungliche) form of norm genesis based on scandalous events, which are worldwide reported by the mass media. [...] One is then not bound to comparing legal text and behavior, to extract from this the conclusion, if something violated the Law, or not. In a much more immediate level, the scandal can itself generate a norm (that was not even formulated beforehand). [...] "Only and firstly by its violation and the corresponding indignation (Empörung) of a colère publique mondial in the fashion of Durhkeim, human rights acquire its justification of validity.” "A legal formatting (juristische Formgebung), a regulation of international public Law, can only connect itself to it, but does assume the role of a legal source" (1992a, p. 27-28). ${ }^{27}$

Luhmann then enlist cases that would be framed as distinctively exemplary, naming them “manifest experiences of injustices” - i.e. “Injustice at any rate!” (“Unrecht auf

26 LUHMANN (1991, p. 273f) distinguish justifications of validity from the conditions of validity. Whereas the justification and "legitimation" would comprise both the production of validity (Herstellung von Geltung) and the provision of motives or reasons (Angabe von Gründen) (1995b, p. 218), the conditions of validity, on its turn, would presuppose the difference between valid and invalid Law. Luhmann goes on to say that the conditions of validity of the legal system in modernity is to be understood as the positivity of law itself - as the symbolic circularity of the "symbol-validity" is something that keeps the continuity in the discontinuity: i.e. the operationality of the legal system itself (1991, p. 280f, 1993a, p. 114f). Here I am referring to the fact that "scandals", even if seemingly influential on the plane of the "justification of validity", are not very "connectively able" ("anschlußfahig") on the plane of the "institutionalization" and not studied with relation to those "conditions of possibilities" that the early Luhmann (1965, p. 22f, 84f.) called the "ambiance" of the legal system. One other issue here is that the claim to "supra-positivity" of human rights (and the "paradoxical" need of their positivation) leaves the situation of human rights validity an "unclear one" (1995b, 221). This seems to be a specific problem of human rights, whose "status" as being "internal" to the legal system (to be read without ontologization!) is arguable. Luhmann leaves this question open. Others also focus more on validity justifications than on conditions of possibility of the scandal itself (see FISCHER-LESCANO, 2005. For scandals as "informal and peripherical elements in the transmission and circulation of the validity symbol”: idem, 2013, p. 93f).

27 Even though Luhmann seems to handle the paradox of the violation of a norm, that was not formulated beforehand as being something specific to human rights, he strangely does not relate the issue with his considerations on the "circularity" of the validity of the legal system, even though it follows similar patterns. In fact, when writing on the "evolution of the legal system", Luhmann formulates exactly this when considering the "variations" within the legal system itself: "That certainly happens retrospectively (nachträglich), on the occasion of a behavior that, on the hind sight, shows itself as a frustration of an expectation. The case makes the norm visible, a norm that did not exist as a structure of social communication before the case. Ex facto ius oritur" (1993a, p. 257, emphasis added). Luhmann goes further to expressively reference directly (FN 45) the formulation concerning human rights: "we will use these considerations, when addressing the issue of the evolution of "human rights" in the contemporary world society". Although linking both through cross-reference, Luhmann does not, however, develop the difference between the Nachträglichkeit and norm-visualization of "legal cases" and "human rights scandals". For a good 
jeden Fall!"). Most importantly, they are the ones that correspond to the clearest and most evident "shocking violations of the most basic measures of human dignity". He further states that

[...] the evident, flagrant indignation (Empörung) could only be spoken of in relation to human rights [...] those who react in these cases with indignation and express their contrafactual expectations do not need to expect dissent - almost as if the normative sense would be covered by a sacral power (LUHMANN, 1992a, p. 28, emphasis added).

But how does a scandal become scandalous? And isn't “the evident Brazilian inequality" also a case of "injustice at any rate?”, Unrecht auf jeden fall? How does it relate to justifications and conditions of law and human rights? How does it result that daily phenomena, that historically where not considered scandalous beforehand, are then considered as "self-evident" (human rights) scandals? More importantly - why and how were the reactions to these scandals selected and liked to human rights semantics (and not to any other semantic)? How are ideas and conceptions of "injustice at any rate" (Recht auf jeden Fall) communicated and operated socially? When and how does a legal form connect itself to it and when not?

Here, it seems that ahistorical or "ontological” conceptions of scandal and human rights cannot take us much further. Sociologically, scandals can only be understood in relation to social evolution - that is, in the interplay of semantics, social systems, forms of public sphere, and diffusion media. These are "blind" and contingent developments, that are not either oriented by transcendental justification patters, nor do they result in a teleological, progressive "success history" (Erfolgsgeschichte) (For Human Rights: HOFFMANN 2011; for scandals FÖGEN, 2003; BRUNKHARDT, 2015).

A somewhat varied "field" of studies on the history (and theory) of human rights, arranged by some under the label of "human rights genealogy" (HOFFMANN, 2010) ${ }^{28}$ take to the center of their analysis precisely the historical contingency of the "emergency" of universalist declarations of rights and, incidentally, faces the social, politi-

analysis and further development of the concept of Nachträglichkeit in social structures and semantics - including the problems of translations of the term (between the English "deferred action" and the French "après-coup") - see STÄHELI, 1998.

28 I thank Mahmoud Bassiouni for the discussions and kindly provided references about the matter in the seminar we held together at the department of political theory of the Frankfurt University in 2015-2016 called "Genealogien der Menschenrechte". 
cal, cultural and historical conditionings of that, which not only is considered "scandalous", but also whose "protection" acquire the legal form of universalist rights.

Human rights, as a modern “evolutionary achievement” ("evolutionäre Errungenschaft") only came about in its modern form at least in the "revolutionary explosion times" of the late $18^{\text {th }}$ Century (and those post-2nd War) and its Declarations (HUNT, 2007). However, these “explosions” are insufficient to explain how human rights came about, if they are not related to the semantic and system relevant "achievements" in the interplay of revolutionary moments and "longue durée" processes. For instance, without the "epistolary novel" and the discovery of our "selves and bodies", and the accompanying "culture of empathy", human rights could not be declared as self-evident (HUNT, 2008, p 35f, 70f). Without individualism, the fall of natural rights semantics and the emergency of the form of subjective rights, the legal form of human rights could not be considered (JELLINEK, 1927, LUHMANN, 1993b). Without a study on the "formation and the changes" of "social values", (especially in the sense of a "sacralization of the person" - JOAS, 2011) one could not explain that "sacral cover" over human rights, to which Luhmann referred above, and how the scandals of its "profanation" work. That also does not show how contemporary human right cases (and scandals) are necessarily selected by a (contingent and historical) "topos" of human dignity protection (LADEUR and AUGSBERG, 2008, p. 105-106, expressly referring to Luhmann's thesis). Moreover, the communication of scandal process and human rights semantics also depends on the available media constellations (VESTING, 2015 p. 121 BRUNKHARDT, 2015, p.85f), social movements (FISCHER-LESCANO 2005, 2007, 2013) and political opportunities scenarios (MOYN, 2010, KOHLRAUSH, 2005). One could quote many other selections that were and are key to understanding human rights scandals as not being something coming from "the world outside" - aus der Welt da draußen (FÖGEN, 2003).

But the main point here is that this crude flight over theories of human rights makes it already clear, how demanding of presuppositions the contingent history of human rights (and of the scandals of their violation) is. Even if we are to make a "history of the present", laden with "sociological presentism", it is hard to speak of a "direct, immediate" genesis or justification of validity of human rights in this strong sense, without falling into an ontology of scandals. This thesis of linking scandalization as receives many criticism and proposals of development (overview in RIBEIRO and EGİO, forthcoming), but cannot be addressed here. Instead, one could see, as argued below, that 
"scandals" can also acquire a parallel "reality rendering effect", and effect of cognitive and normative "immediateness" and "concreteness", that parallel Luhmann's considerations on exclusion and those of the broad "sociological studies on Brazilian reality".

\subsection{Understanding Scandal as legal sociologists: A detour through theology and conceptual history.}

An already classical study on the history of the concept of "scandal" was brought about by the theologist Gustav STÄHLIN (1930, 1961), whose analysis points out to a complex history mainly by analyzing bible translations (in English, see THOMPSON, 2000, p. 11f). In summary, the first profane usages of the term are found in an Aristophanes' comedy. Here, relating to a court procedure, the "spectacular" accusation speech was metaphorically compared to a "scandal" ( $\Sigma \kappa \alpha v \delta \alpha \lambda \eta \theta \rho o v$ - Skandalethron), for the word denoted the piece of wood, a trigger (or spring), used in traps (Stellholz) to catch and imprison animals. It encompasses the notion of a sudden unexpected and violent struck alongside the ruin of the animal stroke and trapped, with the derivation $\Sigma \kappa \alpha ́ v \delta \alpha \lambda$ ov (Skandalon) also probably incorporating the meaning of acrobatic artists (Balancierstangenkünstler) with great, entertaining and unexpected leaping movements. (1961, p. 339, 1930). ${ }^{29}$

But it was with the Septuagint translation of the Old Testament that the term gained its broader and more complex religious connotation. STÄHLIN defends the thesis that a "secondary conceptual assimilation" (1930, p. 130; 1961 p. 341) took

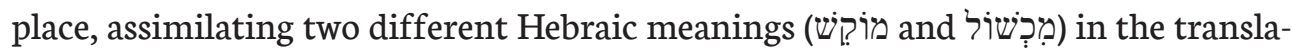
tion to the Greek "Skandalon" ( $\Sigma \kappa \alpha \dot{v} \delta \alpha \lambda o v)$, resulting in a religious concept of both a violent blow that struck or entraps someone down, as well as obstacle in the path, a collision, a stumble stone (Stolperstein and Stein des Anstoßes). The latter becoming the "occasion of religious ruin that could, at the end, imply in the need for a godly tribunal (i.e. Last Judgment; eschatology). ${ }^{30}$

29 For English (Eng.), " $\Sigma \kappa \alpha \nu \delta \alpha \lambda \eta \theta \rho o v$ ", "lignum decipulae incurvum; tendicula. a crooked stick on which the bait is placed in a gin or trap. Metaph., a trap, or snare” (MALTBY, 1830, p. 603). STÄHLIN states that the stem $\sigma \kappa \alpha ́ v \delta$ - is probably related to the Latin "scando" (German (Ger.) - "steigen", Eng. climb, rise), and to the Sanskrit skandati (Eng. he jumps - Ger.: er springt), where the verb was used to describe the rapid movement and impact of a snapping trap and the noun referring to the stick or trigger of a trap. In a "pars pro toto assimilation", it meant also the trap itself." (STÄHLIN, 1961, p. 339).

30 For English also BRYAN, 1998 p. 8f. One finds 22 occurrences of "scandal" and its derivates in the Septuagint. STÄHLIN states (1961:340) that the „sekundäre Bedeutungsassimilation, i.e. assimilating, conflating, the meaning of 
The boom of the concept and its ambivalent usages is attributed to the New Testament. In the Vulgata the term acquired a much more differentiated meaning and appeared 44 times, doubling the frequency of its appearance in the Septuagint. If in the Old Testament, scandal was understood as an associative network of legal-like violations, shames and sins in semantic opposition to "justice and costumes", in the New Testament the term acquired a characteristic of a sin of "spiritual downfall" resulting in a grave menace to the Will of God and to Christian Faith". It was also seen as a test for the Christian community, that should react with indignation of damaging violations. (STÄHLIN 1930, 1961, THOMPSON, 2000, p. 12f, BURKHARDT, 2015, KÄSLER, 1991, p. 69f. For “contemporary tests”, see De BLIC and LEMIEUX 2005). Theologically it acquired a great differentiation in relation to "positive and negative" scandalizations (such as the "positive" scandalization of Jews brought about by Jesus, and the many uses of "negative and positive" scandals in the New Testament, see e.g, FOUSSIER, 2009, AQUINAS, 1947). ${ }^{31}$

Between the $1^{\text {st }}$ and $8^{\text {th }}$ Centuries the term then undertook a growing moralization, popularization and psychologizing features, in which the term usually meant outrage, indignation, social disturbance in conscience and society (STÄLIN 1961, BRUNKHARDT 2005, p. 67f, KÄSLER, 1991, p. 70f). A very important point, is that in German discursive realm, this is the most prominent usage of the term, especially after the translation of Martin Luther of the "scandal” as “Ärgernis” (“indignation",

two concepts consisted in conjoining two different "frames of meaning": On the one hand, (A) the verb "jakasch"

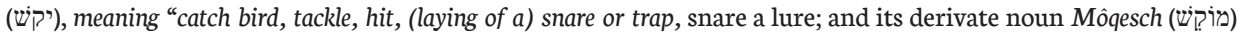
(Ger.: Schlagholz), meaning the medium of hitting a pray in a trap, but also trap itself. Most importantly, meaning also an "occasion of ruin". On the other hand, (B) the verb kaschal (כשל), lead us to another "imagination framework", meaning to "stumble" (fall, fall after an impact, "fail”). The derivate noun Mikschôl (מִּ (obstacle, stone or block in one's path, stumbling-block), over which one stumbles and falls out of the righteous path. When conjoining both meaning frames, the term acquires a broader religious meaning, meaning an "occasion for (spiritual) ruin" or for sin and, consequently, a reason for penalty or punishment (for more equivalents and secondary meanings, see STÄHLIN, 1930, p. 88ff). The point is that, in the Septuagint, the Hebraic words Môqesch (משị) and Mikschôl

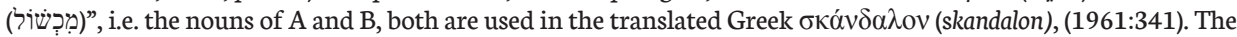
term acquires then a "surplus in meaning", a religious one. As occasion of spiritual ruin and impact caused. Here the impact, obstacle and impulse are amalgamed. On could say it is and impact (Ger. Stoß), that can be understood as a "violation" (Verstoß) and danger to faith and sometimes an stimulus or impact (Anstoß, Anstoßstein) to the need of expiation (Anstoß zum göttlichen Gericht), i.e Final Judgment or eschatology (1961: 341).

31 In the same way that it was in the Old Testament (OT), " $\sigma \kappa \alpha ́ v \delta \alpha \lambda o v$ still denotes, in the New Testament (NT), a relation to God: it is both an obstacle on the faith and a cause to lose faith. Similar to the OT, it is both cause of guilt and downfall; "because the fall from faith is the most meaningful downfall." (345) If the OT was more related to the violation of costumes and laws, the NT adds the meaning of seductive occasions for sin and downfall. There are 44 references to scandal in the NT. The scandal is also understood to express when men "only think and want humanly, therefore coming in opposition to God and His will, making men [in scandal] a tool of Satan”. (1961: 347-8). For other uses, especially in Paulus and on the theme of crucifixion, STÄHLIN, 1961: $352 \mathrm{f}$. 
“outrage”, see SEIL, 1971 p. 504-5), something that stresses mainly the outward and active part of the theological concept and that somewhat hindered the reception of the theological debates on the concept.

In the $12^{\text {th }}$ and $13^{\text {th }}$ Centuries the term acquired a remarking theological and moral relevance (SEIL, 1971, NEMO-PEKELMANN, 2007, FOUSSIER, 2009 for a partial table with authors and themes on scandal of the period: BRYAN, 1998, p. 315). Alongside other prominent works, the theme gained prominence by the extensive classification and development undertaken by Thomas von Aquinas'(1947[1272]) Summa Theologiae (II, IIa, cuastio 43). Aquinas develops extensively on scandals as a sin "opposing beneficence" and "against charity" (i.e. "unjust against the love of the neighbor"32), because it can constitute the loss of "common moral reference points" and the permanent possibility of indiscipline and disorder. The main point here is the link between scandals and the character of exemplarity (reference to a third party -the "neighbor" - proximum) and bringing the "spiritual ruin to your neighbor and the whole community".

This theological tradition (and some of its resonance in Philosophy) is already known and was somewhat studied by sociologists of scandal(e.g. KÄSLER, 1991, BRUNKHARDT, 2015). Nevertheless, besides the insights that the history and etymology of the term can offer, the importance of the scandal in theology and moral philosophy, however, do not make justice to the foremost social relevance that term acquired as a "legal terminology" (SEIL, 1971) and a "catégorie juridique" (FOSSIER, 2009) in the doctrines of Cannon Law, specially by its applications and interpretations of the theological mandate made prominent in these centuries: “avoid the scandal!" - "proter vitandum scandalum”.

\subsection{And a return from theology and back to legal sociology, social normativity and institutional selectivity. The missing institutional link}

The theological origins and developments of the concept are already well known by the main contemporary studies of the "sociology of scandal" (e.g. in Germany, EBB-

\footnotetext{
32 ..."beneficentiae opponuntur",...“contra caritatem”, ...“iniuste proximum” (AQUINAS, 1947). For a leading study discussing the "political theology of the neighbor" in addressing fundamental rights, see the proposal of VESTING, 2014. For the theme of human rights, in a somewhat parallel manner to this essay, see Hauke BRUNKHORST's $(2005, \mathrm{Ch} .1)$ analyses of some pre-formulations of the solidarity terminology in similar semantics of caritas and brotherhood in the Middle Ages. He then follows to undertake a semantic genealogy of solidarity and human rights.
} 
IGHAUSEN and NECKEL, 1989; for the USA, THOMPSON, 2000 for France, De BLIC and LEMIEUX 2005). However, they mainly refer to it only for expositional reasons - i.e. almost encyclopedically setting an "interesting" historical background, but not gaining from it more than only some insightful incentives for "new" hypothesis (some of them farfetched). This is not meant here as criticism. These studies are groundbreaking in setting in motion the framework for the sociological study of scandals. In doing so, sociology will probably use history for the "presentism of its research aims", that is, in great leaps and simplifications (ASSMANN, J. 2002, 400f). That is not a problem, but also a virtue of the field. Following the leading study of scandal and gossip in group dynamics by Max GLÜCKMANN (1963:315), one great aim of social sciences is to transform "common sense" phenomena in sociology, questioning for social functions of all phenomena of the social, no matter how seemingly idle they may seem at first glance. One possible contribution of further studies is specially that of linking this theological tradition to social phenomena. Scandals are volatile and multifaceted. They do not form proper "concepts", theories nor semantics or ideology. The lack of deeper to sociological theorization does not stand could face the dangers of following normative generalizations of positive or negative sides of scandal in a moralizing way (as for "good" or "bad signs" for democracy EBBIGHAUSEN, 1989). Alternatively, only focusing the theological tradition of the concept, one could try to develop a (weak) "political theology" of scandal (trying to follow the steps of Schmitt or Girardi). That is not the case here. ${ }^{33}$

As LEVELEUX-TEIXEIRA (2013: 202) states, it was mainly with the canonists, more than with the theologians, that "'horreur du scandale" manifested itself more presently. And institutionally. For her, "whereas the Theologians were more focused on moral issues", and "even if the moral aspects are also incontestably present in the discourses of the canonists", the latter "privileged the question of collective organization and communal identity". Historically, one potentially productive missing link for the sociological broadening of our understanding of scandal seems to be Canonic Law. ${ }^{34}$

33 A "political theology of the scandal" seems to be problematic, because "scandals" neither "pregnant concepts of State Law and State theory", as proposed by Carl Schmitt, nor institutionalized in the sense studied by Ernst Kantorovic in his "The Kings Two Bodies”. There is, however, some attempt to develop a sort of "political (sociological) theology" of scandal: see GIRARDI (2014). This essay distance itself starkly from this perspective and moral considerations - even though his mimetic theory may provide some loose insights on scapegoating in scandals.

34 I greatly thank Prof. Thomas Duve, director of the Max Plank Institute für europäische Rechtsgeschichte (MPIeR) in Frankfurt for his time and availability in discussing these themes with me. I am also grateful to many of the members of the same institute, for the discussions on Cannon Law and Theology of scandal on the occasion of my 
One can summarize some findings of these studies: (1) Following the theological boom of the scandal theology of the $11^{\text {th }}$ and $12^{\text {th }}$ Centuries, Cannon Law incorporated mentions to "scandal" in its doctrine. Incidentally, scandal is present in many articles of the Codex Iuris Canonici (CIC 1917, 51 entries, CIC 1983, 28 entries; see the commentaries in NAZ, 1965) and the mandate "avoid the scandal" (propter vitandum scandalum) is said by some to have been suitable even for providing a "legal and normative standard" in (medieval) Cannon Law. In this sense, it was applied as a "loose and empty signifier", as a "pure significant" and "notion of variable content" - "une interface juridique flottante" - so that "norms of popular and common knowledge could be linked to Law." (NEMO, 2009 p. 491, LEVELEUX-TEXEIRA, 2013 p. 200 and p. 209).

(2) In its growing usage and significance, the concept was strongly used in the disciplinary system of cannon Law. First and foremost, in the realm of the normalization of the behavior of clerics (FOUSSIER, 2009, NEMO-PEKELMAN, 2007, MEYER, 2011). Here, the mission of the clerics put them in a position of highlight, and their public behavior should be one of setting good examples. This correspond to the assumption, both in theology (as in Aquinas) and in contemporary sociology of scandal (see EBBIGHAUSEN, 1989), that positions of "condensed attention or prominence", representation and power are usually more prone to scandals, being exemplarity a defining characteristic. Theologically, the image of the Holy Church, its divine mission, and the theological mandate propter vitandum scandalum (whose emergence itself could cause spiritual ruin and consummate a mortal sin), were specially at risk when the public image of the clerics was at stake. However, the legal relevance of the term scandal was progressively broadened to include the "disciplinarization" of the Christian population and, later on, even of laics (FOUSSIER, 2009 MEYER, 2011, FOUCAULT; 2014, p. 175 f.). It was so, for what was at stake by the emergence of scandals was the very (spiritual) tie of the community. As in Aquinas, neither intention nor veracity are primary in constituting scandal, but exemplarity. The "disciplinary legal institute" of scandal progressively became a marking for disciplinary measures of public conduct in Europa of the $13^{\text {th }}$ century (FOUSSIER, 2009, NAZ 1965, BRYAN, 2008). May it be in the emerging "public administration" of the $12^{\text {th }}$ Century Europe (MEYER, 2011) or in the "derecho indiano" of the Spanish colonies of the $17^{\text {th }}$ Century (AGÜERO, 2008). This “disci- 
BETWEEN SCANDAL AND INVISIBILITY:

plinary character" of the canonic scandal doctrine was key in shaping the relations of canonic and public disciplinary powers. As it can be seen in the "Letters of the King (cedulas reales)" addressed both to Bishops and public servants in AGÜERO (2008) and ESCRICHE(1863).

(3) Moreover, the concept was said to be crucial for the differentiation between "sins and crimes". It operated in this context as a "legal marker" to distinguish, on the one hand "private sins and crimes" - that were regulated in private fora with private penitence, confessions, forced displacement of clerics from one parish to another -; and, on the other hand, public sins and crimes, whose penitence and punishments, or expiation rituals, where to be held publicly (See comments in NAZ, 1965). Scholars such as Christoph MEYER (2011, p. 133, 145), state that this differentiation, could be thought to even mark the beginning of the development of the "public sphere or publicity (Öffentlichkeit) already in the Middle Ages, in which the "scandal concept" was a central operative concept in the co-evolution of Politics, religion and Law (at the time still un-differentiated), in the sense that by rituals, legal-canonic procedures and cases, scandals would perform the difference public/secret (Öffentlichkeit/Geheim - See also FOUCAULT, 2014). FOUSSIER (2009), BRYAN (2008) and NEMO-PEKELMAN (2007), even state that the "scandal doctrine" and the mandate "propter vitandum scandalum" were key to attribute more prominence to the development of the institution of the "confessionary". To avoid scandal was both a justification and a "guide-line" (manuals) of confession distributed to clerics (REX GALINDO, 2016).

(4) Lastly, scandal and the (legal) argumentation by scandals ware also a form of "evidence and truth obtaining" for the legal system of the time. Departing from the notion that the "scandal" is per se a completed and consummated "evil", whose immediate consequences could lead to the occasion of spiritual ruin of the neighbor by means of a "bad example", only the appearance of scandal could suffice as means of constituting evidence. (MEYER, 2011, p. 133).

The very emergence of a scandal signified immediately its consummation as a dangerous sin against faith and community. The scandal is then both the evidence of a sin and a sin in itself. It is not by chance that truth and evidence-searching of Law by "scandal argumentation" appear at the side of other forms of public "truth and evidence producing" in Law, such as trial by combats, by God or by ordeal, that were latter on substituted by torture (FOUCAULT; 2014, AGÜERO 2008, LEPORE, 2016) and by the Trial by Jury. All of those constitute evidence-obtaining or legal-truth producing 
procedure based on public ritualized procedures. However, also regarding truth was scandal ambivalent. It was at times an evidence-producing phenomenon, performatically constituting a sin or offence before the Law and providing simultaneously evidence of this sin. In other cases, the opposition to truth was so grave, that the scandal should be pondered (LEVELEUX-TEXEIRA, 2013, p. 196). The mandate to avoid scandal meant often to occult the truth, something that was theologically and canonically problematic, especially considering the doctrine of the "triple truth" or triplex veritas (see NEMO-PEKELMANN, 2007, BOHLEN 1836, p .97, AQUINAS, 1947).

However, considering the necessity of "avoiding scandal”, what the institute rendered was a greater margin of appreciation and openness for casuistic decisions: "The paradox is that this same scandal, which in some cases leads to a strengthening of social control by the law, can also result in other hypotheses, on a phenomenon of deregulation or disregard of the Law" (LEVELEUX-TEXEIRA, 2013, p. 210 see also, AGÜERO, 2008, p. 169f). ${ }^{35}$

\subsection{Final remarks}

These findings point out that scandals were not only relevant for abstract theological discussions, but manifested greatly in the shaping of legal and normative institutes. Even if one cannot follow a conceptual history of scandal or a semantic of scandal, one can see that the relations between scandals, normativity and human rights, are quite more complex than inferred by Luhmann. Maybe one should address scandalizations more as "communication processes" (BRUNKHARDT, 2005). It also points out to difficulties in relating scandals only to chance, or to "unpredictable" reactions of ontological references such as "events", "the a-priori feelings of an outraged public”, "democratic or public reason", generation of norms or "transcendent moral intuitions" or attributing to them an essentialist "good", "democratic", value, or, conversely, a natural "bad and culture-pessimistic" element (See debates in EBBINGHAUSEN an NECKEL, 1989). The issues of present day discussions of scandals must however be left open

\footnotetext{
35 The study of the canonical and moral-theological tradition of the scandal remains important, not only for some old traceable connections to fundamental texts. This is the case of KANT's, in his Perpetual Peace, uses of the theology of Scandal as "validity justifications" for constitutional intervention. PIEVATOLO(2013) shows that Kant's "non-interventionism" of his fifth preliminary article of Perpetual Peace relies mainly on the distinction of scandalum datum and scandalum acceptum.
} 
for further debates. The focus here should suffice to show neither a philosophical or etymological, nor a the "reactive" approach to scandals suffice for a legal sociological approach of a very complex phenomena.

In 1972, Luhmann stated: "unfortunately there is almost no study on scandal, that is not itself scandalous" (LUHMANN, 1972, p. 62). As seen above, this lamentation does not correspond, however, to the new state of the literature. In this work, the young Luhmann also developed more specific considerations linking scandals to normative expectations that, unfortunately, were not transposed to his further considerations on the validity justification of human rights.

In his latter works Luhmann develops these considerations but does so without reference to human rights or the legal system. (1997, p. 763f, 854f). A leading and innovative study of a sociological luhmannian approach using "scandals" to analyze Roman Law history was set forward by Marie Therés-Fögen. Fögen argues that scandals are only but a moment of "variation". The problem of "selection" ("the ordeal of decision") is but a greater one and depends on the co-evolution of social systems and semantics (see also STÄHELI, 1998). For her, in the very contingent cases that scandals are followed by successful selections, scandals can mark an "event" (Ereignis) for a system, that is, a relevant "before/after" distinction. Scandals can therefore work similar to KOSELLECK'S (1992) concept of crisis: i.e. they present a scission (eine Scheidung) that must be decided (ent-schieden werden, de-cided). In this sense, scandals can sometimes work as a "negative marking” for "values" or "norms", by bringing their supposed violation or endangerment to the center of the "condensing semantics" of attention. They may take part, as negative markers, in the crystallization of "values", the latter being a "reflection stop" (FÖGEN, 2003 for value-theory and their problems, Luhmann, 1965, also, concerning, scandalizations, LESCANO 2005, 2007, 2013). In their justifying and legitimizing function, scandals can (in very few cases!) work, in relation to a given system, as "a narrative of the beginnings" or as "symbolic big bang” especially by performatively introducing the beginning of the negative side of the code. For the legal system, it means: the emergence of the "Unrecht” (unlawfulness or also “injustice”. FÖGEN, 2003).

The founding of a narrative of beginnings, or "origin", can only begin with the negative side: “Am Anfang war Kein Unrecht” - At the beginning there was no unlawfulness (or injustice), is the title of an article by Luhmann. Both Luhmann and Fögen argue that the "beginning" can only be inquired once a given system is already in operation, and always in hind sight (nachträglich-FÖGEN; 2003, p. 77f). Grave human rights 
violation scandals can, albeit very seldom, function in this way. This is also the assumption of those studies above conjoint by the label of "genealogy of human rights", that, following the genealogical assumptions, do not assume a non-contingent birth or origin of human rights that can be pin-pointed, for all evolution is considered complex and contingent. Moreover, even constitutionalism would be in need of "myths of origin” (VESTING, 2011, KOSCHORKE, 2007, p. 7f).

More than only being part of an epistemological-normative "reflection-stop", "justifications or myths of origin" in legal and political systems are constantly re-interpreted and actualized in different historical, social and cultural constellations (ASSMANN, 1999, and for the issues of human rights violation scandals, idem 2013). Even if we assume, as Fischer-Lescano correctly shows, that human rights scandals can foster the "informal symbolic circulation of the validity of human rights" and a socio-legal aesthetics of contestation (2013), the thesis of scandals of human rights violations say very few about the conditionings of these violations, and much less on the evolutionary achievements of human rights enforcement and development that occurred without scandalization.

One could also say that scandals concerning "exemplary experiences of injustices" could contribute to fostering our "imagination of barbarianism" and of "naked lawlessness" that renders "evident" some universalist semantics as the negative side of universal claims" (see BURUCU'A and KWIATKOWSKI, 2014 in the evolution of social representations of mass killings). They become "evident", for they appear before our eyes (the shared eyes of a assumed community) in an image-like fashion, with excitement and concreteness. In the specific case of human rights, (see RIBEIRO AND EGIO, forthcomming) the iconography of human rights violations encompasses the wounded "bodies" (traumatized bodies and souls), that could eventually feed a response to "cultural traumas” (JOAS, 2011), rendering “plausibility” (LUHMANN, 1997, p. 500f) to a cultural and legal semantic of "universal (or inclusive) legal-like claims. This does not lead us further in understanding how scandalization processes work and function in society. For what we have seen above, scandals have a much more complex nature as social processes. They show shared evidence and draw attention, being a performatic discourse (BLASBERG, 2007) ${ }^{36}$

36 We use "scandals" even in theoretical and scientific argumentation, to set the premise and axioms of works See, e.g., the opening of Teubner's book (2012, p. 1): “a series of human rights scandals...” sets the pointing premise to support his claim that we are now facing the "new global constitutional issue". There are those who even say that 
Be as it may, the latter Luhmann's considerations on human rights scandals seem to rely on an evidence-rendering visual metaphoric, with the same or parallel dangers of ontologization and personification that underlie his exclusion/inclusion debates. One may note, that the above considerations of this essay show some paths to broaden this perspective, relying less in a "impressive seeing" and more on a "sociologic" perspective. But the main point to be taken here is less one of the tradition of the scandal semantics in texts and philosophy. In the same way as argued above with the inclusion-exclusion debate, the legal sociology approach on scandals could also be set forward less as a result our "impressive seeing" and more as a theoretical challenge for legal sociology.

\section{Coda - "Human rights for the righteous humans!": the scandalizing example of the Sonderweg-Brazil in transitional human rights (or: contrast foiling Argentina's case)}

Returning to our main theme in an exploratory and concluding manner: Brazil is said, once again, to be a Sonderweg also in matters of transitional human rights in Latin America (SCHNEIDER, 2015). One of the main comparisons to assert the "peculiar position" or "singular path" of Brazil in the region, is the contrast foiling 37 of the Brazilian case with the Argentinean one (for a system theory analysis of the Argentinean case see the leading studies: FISCHER-LESCANO 2005, 2007). The Argentinean case became a positive paradigm to understand "scandalization of human rights violations" inserting the issue of the "desaparecidos" in the vocabulary of human rights - including with some saying it marked a key change in our imagination frameworks and "representation formulae” of "historical massacres” (BURUCÚA and KWIATKOWSKI, 2014). Therefore, human rights movements successfully used an "economy of attention" in a time of a Soccer World Cup in 1978, adopting State terrorism and "desaparición forzada" as "battle cries to scandalize social conflicts” (TEUBNER, 2012, p. 242, and FISCHER-LESCANO,

Luhmann decisively formatted his theory as "scandalizing" the sociologic community to propose his paradigmatic change (as IZUSQUIEDA, 2008, p. 77f. Also the preface of LUHMANN, 1984, arguing that his theory would face a paradigmatic crisis of social theory, relying on the terminology of Thomas Kuhn). For scandal in rhetoric, see BLASBERG, 2007.

37 SCHNEIDER calls Brazil a contrast foil (Kontrastfolie) to Germany, and states: "the contrasting case of Brazil should be used to critically enlighten the social inequality that is contemporarily growing strong in Germany" (2011, p. 8 emphasis added). She also coins the term that Brazil would be a "Latin-American-Sonderweg" in transitional human rights (2015). 
2007 and 2013). That is a positive finding and theorization. However, a deepening understanding of the relations between human rights and scandalizations (as their validity justification) could profit from a broader theoretical understanding of scandal alongside other case analysis both of "non-scandals” or counter-scandalizations.

“Contrasting” Argentina, in the Brazilian case, after the Supreme Court (STF) decided, in 2010, against recommendations of the Interamerican Human Rights Court, to not revise the Amnesty Law of 1979 (ADPF 153), the Truth Commission of Brazil only came to turn in 2013, being made publicly accessible also on the eve of a World Cup. But what followed, in terms of human rights, was a "non-scandal" and a "counter-scandalization". The attention was shifted and quickly refocused on the corruption scandals attributed to the Government in 2013 and 2014, alongside the "scandal-driven" Operation "Lava Jato". Mass protest were accompanied with an intensification of openly anti-human rights battle cries such as "direitos humanos para humanos direitos" - an antithetic chiasmus or antimetabole that could be translated to - "human rights for the right(eous) humans."

Although there has been, in Brazil, an organized civil society that actively fought for decades for "the right of memory", broad discussions on the public sphere, public incentives on "cultural memory", (among many, the cited works of SCHNEIDER, 2015, 2016) not only was the publication of the "Truth Commission Reports" a non-scandal, but it faced a counter-scandalization: human rights being chanted to be of the "leftist wing", "only for protecting the criminal". Human rights ministries were thought to be useless, corrupt, and too expensive and suffered severe cuts in the following Temer Government. Huge mass-mobilizations of the civil society, following the normative check-list of the "civil society and new social movements" (transclassist, without party, spontaneous, pacific, loosely and independently organized) theory were on the streets, many of them manifestly against a semantic of human rights. (see RIBEIRO, 2012, Ch. 5).

How to address the issue? A longstanding "weak" Brazilian political culture seems to be a too simplistic way out - or at least only one facet of the bigger picture. The same happens if we quasi-ontologically ascribe the problem to the all-explaining "Brazilian Sonderweg”. Moreover, chronological “recipes” or models for transitional justice in neatly fashioned tables or once again comparing the "vileness" of Brazilian VS. Argentinian dictatorship seem to lead to dead ends, especially for legal sociology”. Of course, longé dureé exclusion patters are, yes, to be blamed for a great deal of the guilty, but they cannot close the picture. Instead of only addressing the issue of "the Sonderweg Brazil" 
with its peculiarities, maybe one should also address the difficulties in only positively and retrospectively linking scandals to human rights, i.e., when they are successful, such as the case of the "Madres de la Plaza de Mayo". Instead of bringing a "carnivalesque" Brazilian legal-political culture to the explaining, one should also question concepts and address the issue in a more critical matter. ${ }^{38}$ Maybe, one could once again turn to Brazilian legal sociology, that once showed that "exclusion" is a much more complex issue and extremely influent in understanding fundamental rights and constitutional efficacy. As Luhmann himself stated, one should look more to the "ambiance" of fundamental rights in a more developed way, not with unquestionable binary distinctions or with light metaphoric.

The same could be said here regarding the consideration of human rights violation scandals. Instead of only condemning Brazil (something one must and should also do), maybe the Brazilian "human rights non-scandal" could also serve us as an opportunity to rethink our theoretical presuppositions and "blind spots", such as those of Luhmann, that human rights scandals have (prima facie!) mainly an "evident” relation to the progress of human rights.

This seems to go hand in hand with the studies that show how human rights awareness are contingent, and that the relation between scandalizations, normativity and institutions is not a simple or a given one. Furthermore, the theme seems even more pressing when one notes the current "theme of day" in the media and academia, where one notes an omnipresent preoccupation with the issue of "post-factual era", "neo-populism scandalizations", polarization and scandalization growth; where our social and normative performance of norms and argumentations seem to rely much more in scandalizing scripts then what we call "facts" in the "law of evidence" (LEPORE, 2016), may it be on presidential elections or in the dealings with the refugee crisis. Or, as famously said by HAN (2013, p. 3f), in his Kulturpessimismus of the contemporary "transparent society", we could be facing also the emergence of a "society of scandal".

The aim of this essay was to try to provoke legal sociology in some of its uses (and abuses) of Brazilian reality. It was intended to show how legal sociology is influenced by it, but also how these thematizations of Brazilian reality could productively contribute

\footnotetext{
38 The comparison of "carnival" and scandal is pointed out in the "Historical Dictionary of Rhetoric": "just like the carnival, the scandal is one instrument of temporary critique and long-term stabilization of political and institutional power". Nonetheless, scandals are also conceived as being able to attribute visibility to abstract norms and induce mobilization (BLASBERG, 2007 p. 928).
} 
do its theoretical development. By doing so, the article treaded an eclectic and long path, with great exploratory thematic and historical leaps. It seemed necessary to show the underlying "light metaphoric" and "images" permeating both phenomena usually present in thematizations of Brazilian (legal) reality - exclusion and scandal. Maybe, by addressing these "substructure" of the underlying thematic, legal sociology could gain in deepening these debates, especially when addressing issues related to Brazil - and maybe shedding light to some of its "blind-spots".

By proceeding in this way, this essay may have scandalized some of the academic norms and accepted modus operandi of legal sociology and its public. It is not meant to be, in any way, neither an active scandal nor a "scandalum datum". Nonetheless, if this was the case, one can only resource to the academic public sphere with its rituals and further discussions (paraphrasing MEYER, 2011) to publicly expurgate the academic sins that may have been publicly and shamefully committed here, awaiting further discussions and criticisms, for in theoretical discussions, one shall not avoid scandal: si ex veritate nascitur scandalum, melius est, nasci scandalum, quam ut veritas occultetur.

\section{REFERENCES}

AGÜERO, A. Castigar y perdonar cuando conviene a la República La justicia penal de Córdoba del Tucumán, siglos XVII y XVIII. Madrid: Centro de Estudios Políticos y Constitucionales, 2008.

ALMOND, G.; VERBA, S. The Civic Culture: political attitudes and democracy in five nations. New Jersey: Princeton University Press, 1963.

AQUINAS, St. T. (1947[1272]) The Summa Theologica. Translated by the Fathers of the English Dominican Province. Benziger Bros. Edition, 1947.

ARANTES, P. E. Zero à esquerda. São Paulo: Conrad Editora do Brasil, 2004. (Coleção Baderna).

ARRETCHE, M. “Apresentação”. In: ARRETCHE, M.(Ed.) Trajetórias das desigualdades: como o Brasil mudou nos últimos cinquenta anos. São Paulo: Unesp, 2015, p. 1-22.

ASSMANN, A. Erinnerungsräume. Formen und Wandlungen des kulturellen Gedächtnisses. München: C.H. Beck Verlag, 1999.

ASSMANN, A. Das neue Unbehagen an der Erinnerungskultur: Eine Intervention. München: C.H. Beck Verlag, 2013.

ASSMANN, J. “Nachwort”. In: ESPOSITO, E. Soziales Vergessen: Formen und Medien des Gedächtnisses der Gesellschaft. Translated from Italian to German by Alessandra Corti. Frankfurt: Suhrkamp, 2002, p. 400-414.

BACHA, E. “O Economista e o Rei da Belíndia: uma fábula para tecnocratas”. Jornal Opinião, s/e, São Paulo, 1974. 
BACHMANN, U. “Sammelbesprechung: Soziale Differenzierung”. In: Soziologische Revue, v. 39, n. 2, p. 215-226, 2016.

BACHUR, J. P. “Inclusão e exclusão na teoria de sistemas sociais: aspectos críticos”. BIB Revista Brasileira de Informação Bibliográfica em Ciências Sociais, v. 73, p. 55-83, 2012.

BAECKER, D. Studien zur nächsten Gesellschaft. Frankfurt a. M.: Suhrkamp, 2007.

BALKE, F. “Tristes tropiques: systems theory and the literary scene”. Soziale Systeme, v. 8, n. 1, p. 27-37, 2002.

BECK, U. Was ist Globalisierung? Irrtümer des Globalismus - Antwort auf Globalisierung. Frankfurt a. M.: Suhrkamp, 1998.

BECK, U. Schöne neue Arbeitswelt. Aktualisierte Neuausgabe. Frankfurt a. M., Suhrkamp, 2007.

BIRLE, P.; DEWEY, M.; MASCARENO, A. “Zur Einführung -Luhmann und Lateinamerika”. In: BIRLE, P.; DEWEY, M.; MASCARENO, A. (Ed.) Durch Luhmanns Brille: Herausforderungen an Politik und Recht in Lateinamerika und in der Weltgesellschaft. Wiesbaden. Springer, 2012, p. 7-16.

BLASBERG, C. “Skandal”, In: Historisches Wörterbuch der Rhetorik, Tübingen, 2007, v. VIII, p. 923-929.

BLUMMENBERG, H. Theorie der Unbegrifflichkeit. Frankfurt a. M.: Suhrkamp, 2007.

BLUMMENBERG, H. Paradigmen zu einer Metaphorologie. Frankfurt: Suhrkamp, 1997.

BOHLEN, P. von. “Die Genesis”. In: Allgemeines Repertorium für die theologische Litteratur und kirchliche Statistik. Rheinwald: Georg Friedrich Heinrich Ed. Suppl. 2, v. 14, p. 97-103, 1836.

BORA, A. "Sociology of Law in Germany: Reflection and Practice”. In: Journal of Law and Society, v. 43, n. 4, Dec. 2016, p. 619-646.

BRANDÃO, G. M. "Demokratisierung und Entwicklung: Ein Forschungsprogramm“. In: KÜHN, T.; SOUZA, J. de. (ed.) Das moderne Brasilien Gesellschaft, Politik und Kultur in der Peripherie des Westens, 2006, p. 65-78.

BRANDÃO, G. M. “Linhagens do Pensamento Político Brasileiro”. DADOS - Revista de Ciências Sociais, Rio de Janeiro, v. 48, n. 2, 2005.

BRUNKHORST, H. Solidarity: From Civic Friendship to a Global Legal Community. Translated by Jeffrey Flyn. Cambridge: Massachusetts: MIT Press, 2005.

BRYAN, L. "Vae Mundo a Scandalis”: The Sin Of Scandal In Medeval England. A thesis submitted for the degree of Doctor of Philosophy, 1998 by Lindsay Bryan, Graduate Department of History, University of Toronto. Canada University Library.

BURKHARDT, S. Medienskandale: Zur moralischen Sprengkraft öffentlicher Diskurse. 2. ed. Köln: Halem, 2015.

BURUCÚA, J. E.; KWIATKOWSKI, N. “The Absent Double: Representations of the Disappeared”. In: New Left Review, v. 87, p. 97-113, May/Jun., 2014.

CALDEIRA, M. T. P. do. "Fortified Enclaves: The New Urban Segregation” in Public Culture 1996, 8: 303-328, 2009. 
- PEDRO HENRIQUE RIBEIRO

CAMPELLO DE SOUZA, M. do C. Estado e partidos políticos no Brasil (1930 a 1964). São Paulo: Alfa-Omega, 1976.

CARVALHO, J. M. de. Os Bestializados: O Rio de Janeiro e a República que nunca foi. 3. ed. São Paulo: Companhia das Letras, 1987.

CARVALHO, J. M. de. “Cidadania: Tipos e Percursos”. In: Estudos históricos, v. 18, p. 337-359, 1996.

CARVALHO, J. M. de. Cidadania no Brasil: o longo caminho. Rio de Janeiro: Civilização Brasileira, 2001.

COCCO, G. MundoBraz: o devir-mundo do Brasil e devir-Brasil do mundo. Rio de Janeiro: Record, 2009.

COUTO, C. G.; ARANTES, R. "Constituição, governo e democracia no Brasil”. Revista Brasileira de Ciências Sociais, São Paulo, v. 21, n. 61, 2006.

CUNHA, L. G.; BONELLI, M. G.; OLIVEIRA, F. L.; SILVEIRA, M. N. B. "Profissionalização por gênero em escritórios paulistas de advocacia”. Tempo Social (USP. Impresso). São Paulo, v. 20, p. 265-290, 2008.

DAVIS, M. Planet of Slums. London: New York: Verso, 2006.

DE BLIC, D.; LEMIEUX, C. “Le scandale comme épreuve: Éléments de sociologie pragmatique”. In: Politix, v. 18, n. 71, p. 9-38, 2005.

DOMINGUES, J. M. Teoria crítica e (semi)periferia. Belo Horizonte: Editora UFMG, 2011.

DUTRA, R. Funktionale Differenzierung, soziale Ungleichheit und Exklusion. München: UVK Verlagsgesellschaft Konstanz, 2012.

DUTRA, R. “O Primado da Diferenciação Funcional e a Contingência das Estruturas de Desigualdade Social”. In: D. T., R.; BACHUR, J. P. (Ed.) Dossiê Niklas Luhmann. Belo Horizonte: Editora UFMG, 2013.

DUTRA, R. “Diferenciação Funcional e a Sociologia da Modernidade Brasileira”. In: Política \& Sociedade. Florianópolis, v. 15, n. 34, set/dez., 2016.

EBBIGHAUSEN, R.; NECKEL(Ed.). Anatomie des politischen Skandals. Frankfurt a.M.: Suhrkamp, 1989.

ECKSTEIN, L.; REINFANDT, C. "Luhmann in da Contact Zone: Towards a Postcolonial Critique of Sociological Systems Theory”. Philosophische Fakultät, Universität Potsdam, 2017. Available in: https://publikationen.uni-tuebingen.de/xmlui/handle/10900/82207. Access in: 18 aug. 2020.

ESCRICHE, D. J. “Escándalo”. In: ESCRICHE, D. J. Diccionario Razonado de Legislación y Jurisprudencia. Paris: Librería de Rosa y Bourbet, 1863, p. 627-628.

FAORO, R. Existe um Pensamento Político Brasileiro? São Paulo: Ática, 1994.

FARZIN, S. “Inklusion/Exklusion”. In: JAHRAUS, O.; NASSEHI, A. et al. (Eds.), Luhmann Handbuch: Leben, Werk, Wirkung. Stuttgart, J. B. Metzler, 2012.

FARZIN, S. "Sichtbarkeit durch Unsichtbarkeit: Die Rhetorik der Exklusion in der Systemtheorie Niklas Luhmanns“. In: SINA F., Sven Opitz und Urs Stäheli (Ed): Inklusion/Exklusion: Rhetorik Körper - Macht. Soziale Systeme 14, 2/2008, S. 191-209. 
BETWEEN SCANDAL AND INVISIBILITY:

INEQUALITY, HUMAN RIGHTS AND EFFECTIVENESS OF LAW IN BRAZIL (AND ITS SOCIOLOGY)

FARZIN, S. Inklusion Exklusion: Entwicklungen und Probleme einer ystemtheoretischen Unterscheidung. Bielefeld: Transcript, 2006.

FIGUEIREDO, A. C.; LIMONGI, F. Executivo e Legislativo na Nova Ordem Constitucional. Rio de Janeiro: FGV, 1999.

FISCHER-LESCANO, A. Rechtskraft. Berlin: August Verlag, 2013.

FISCHER-LESCANO, A. Globalverfassung: Die Geltungsbegründung der Menschenrechte. Weilerswist: Velbrück Wissenschaft, 2005.

FÖGEN, M. T. Römische Rechtsgeschichten. Über Ursprung und Evolution eines sozialen Systems. Göttingen: Vandenhoeck \& Ruprecht, 2003.

FOSSIER, A. V. "Propter vitandum scandalum”. Histoire d'une categorie juridique (XIIe-XVe siecles). In: Melanges de l'Ecole francaise de Rome - Moyen Age, Ecole francaise de Rome, v. 121, n. 2, p. 317-348, 2009.

FOUCAULT, M. Surveiller et Punir Naissance de la Prison. Paris: Gallimard, 1975.

FOUCAULT, M. Wrong-Doing, Truth-Telling: The Function of Avowal in Justice. BRION, F.; HARCOURT, B. (Ed.). Translated by Stephen Sawyer. Chicago, IL: University of Chicago Press, 2014.

FOLHA DE S. PAULO; INSTITUTO DATA FOLHA. Racismo cordial: a mais completa análise sobre o preconceito de cor no Brasil. TURRA, C.; VENTURI, G. V. (Ed.). São Paulo: Ática, 1995.

FRENCH, J. D. Drowning in Laws. Labor Law and Brazilian Political Culture. The University of North Carolina Press, Chapel Hill, 2004.

FREYRE, G. (2003[1933]) Casa Grande \& Senzala. Formação da família brasileira sob o regime da economia patriarcal. 48. ed. São Paulo: Global, 2003.

GIDDENS, A.; Runaway World. How Globalization is Reshaping our Lives. New York: Routledge, 2003.

GIRARDI, R. The One by Whom Scandal Comes (Studies in Violence, Mimesis, \& Culture). Translated by B. M. de Bevoise. Michigan: Michigan State University Press, 2014.

GLÜCKMANN, M. “Gossip and Scandal” In: Current Anthropology, v. 4, n. 3, p. 307-316, Jun. 1963.

GRÜN, R. "Escândalos, Tsunamis e Marolas. Apontamentos e desapontamentos sobre um traço recorrente da atualidade”. Revista Brasileira de Ciências Sociais, v. 26, n. 77, p. 151- 173, 2011.

HABERMAS, J. Wahrheit und Rechtfertigung: philosophische Aufsätze. Frankfurt: Surhkamp, 1999.

HOFFMANN, S. L. “Einführung: Zur Genealogie der Menschenrechte“. In: HOFFMANN, J. L. (Ed.): Moralpolitik. Geschichte der Menschenrechte im 20. Jahrhundert, Göttingen, 2010.

HAN, B. C. Im Schwarm: Ansichten des Digitalen. Berlin: Matthes \& Seitz.

HOLANDA, S. B. de (1995[1936]) Raízes do Brasil. 26. ed. São Paulo, Companhia das Letras, 2013.

HUNT, L. Inventing Human Rights: A History. New York, London: Ww Norton \& Co, 2008.

HUNT, L. “The Paradoxical Origins of Human Rights”. In: Wasserstrom et al (ed.), Human Rights and Revolutions. Rowman \& Littlefield Publishers, 2007, p. 3-20. 
- PEDRO HENRIQUE RIBEIRO

IZUZQUIEDA, I. La Sociedad sin Hombres: Niklas Luhmann o la teoría como escándalo. Rubí-Barcelona: Anthropos Editorial, 2008.

JAPP, K. “Zur Funktion der Menschenrechte in der Weltgesellschaft - Niklas Luhmanns, Grundrechte als Institution revisited”. In: HEINZT, B.; LEISERING, B. (Ed.) Menschenrechte in der Weltgesellschaft: Deutungswandel und Wirkungsweise eines globalen Leitwerts. Frankfurt: Campus Verlag, 2015, p. 65-78.

JELLINEK, G. Die Erklärung der Menschen- und Bürgerrechte. Ein Beitrag zur modernen Verfassungsgeschichte. 4. ed. Munich/Leipzig: Duncker Humblot, 1927.

JOAS, H. Die Sakralisierung der Person. Eine neue Genealogie der Menschenrechte. Frankfurt a. M.: Suhrkamp, 2011.

KÄSLER, D. Der politische Skandal: zur symbolischen und dramaturgischen Qualität von Politik. Opladen. Westdeutscher Verlag, 1991.

KNEER, G.; SCHROER, M. “Soziologie als multiparadigmatische Wissenschaft. Eine Einleitung”. In: KNEER, G.; SCHROER, M. (Ed.). Handbuch: Soziologische Theorien. Wiesbaden: Springer VS Verlag, 2009, p. 7-19.

KOHLRAUSCH, M. Der Monarch im Skandal. Die Logik der Massenmedien und die Transformation der wilhelminischen Monarchie. Berlin: Akademie Verlag, 2005.

KOSCHORKE, A. “Zur Logik kultureller Gründungserzählungen“ In: Zeitschrift für Ideengeschichte, 1(2), p. 5-12, 2007.

KOSCHORKE, A. "Das Mysterium des Realen in der Moderne“. In: LETHEN, H.; JÄGER, L.; KOSCHORKE, A.(Ed.) Auf die Wirklichkeit zeigen: Zum Problem der Evidenz in den Kulturwissenschaften. Ein Reader. Frankfurt: New York: Campus Verlag, 2015, p. 13-38.

KOSELLECK, R. Kritik und Krise - Eine Studie zur Pathogenese der bürgerlichen Welt. Frankfurt a. M.: Suhrkamp, 1992.

KRONAUER, M. Exklusion. Die Gefährdung des Sozialen im hoch entwickelten Kapitalismus. Frankfurt: New York: Campus Verlag, 2010.

KÜHN, T; SOUZA, J. "Einleitung: Ein Blick auf das moderne Brasilien - mit Einblicken für die deutschen Sozialwissenschaften”. In: KÜHN, T; SOUZA, J. (Ed.) Das moderne Brasilien Gesellschaft, Politik und Kultur in der Peripherie des Westens. Wiesbaden: VS Verlag für Sozialwissenschaften, 2006, p. 9-19.

LADEUR, K. H.; AUGSBERG, I. Die Funktion der Menschenwürde im Verfassungsstaat. Humangenetik Neurowissenschaft - Medien. Tübingen: Mohr Siebeck, 2008.

LAMOUNIER, B. “A democracia brasileira de 1985 à década de 1990: a síndrome da paralisia hiperativa”. In: VELLOSO, J. P. dos R. (Ed.) [et. al.] Governabilidade, sistema político e violência urbana. Rio de Janeiro: José Olympio, 1994.

LAVALLE, A. G. Vida pública e identidade nacional: leituras brasileiras. São Paulo: Globo, 2004.

LEPORE, J. “After the Fact: In the history of truth, a new chapter begins.” In: The New Yorker. March $21^{\text {st }}, 2016$. 
LETHEN, H. "Vorwort“. In: LETHEN, H; JÄGER, L.; KOSCHORKE, A. (Ed.) Auf die Wirklichkeit zeigen: Zum Problem der Evidenz in den Kulturwissenschaften. Ein Reader. Frankfurt: New York: Campus Verlag, p. 9-12, 2015.

LEVELEUX-TEXEIRA, C. "Le droit canonique médiéval et l'horreur du scandale”. In: Cahiers de recherches médiévales et humanists, Journal of medieval and humanistic studies, v. 25, p. 193-211, 2013.

LIND, M. The Next American Nation. New York: Free Press, 1995.

LÜDEMANN, S. Die Metaphern der Gesellschaft: Studien zum soziologischen und politischen Imaginären. München: Wilhelm Fink Verlag, 2004.

LUHMANN, N. Rechtssoziologie V. 1. Hamburg: Rowohlt Taschenbuch Verlag, 1972.

LUHMANN, N. Soziale Systeme: Grundriß einer allgemeinen Theorie. Frankfurt am Main: Suhrkamp, 1984a.

LUHMANN, N. “Vorwort”. In: SOUTO, C. Allgemeinste wissenschaftliche Grundlage des Sozialen. Wiesbaden: Steiner, 1984b, p. 9-12.

LUHMANN, N. “Ich nehme Karl Marx”. Archimedes und wir - Interviews. Berlin: Merve Verlag, 1987, p. 14-37.

LUHMANN, N. “Weltkunst”. In: LUHMANN, N.; D. BUNSEN, Frederick; BAECKER, D. Unbeobachtbare Welt: Über Kunst und Architektur. Bielefeld: Verlag Cordula Haux, 1990, p. 7-45.

LUHMANN, N. “Die Geltung des Rechts” Rechtstheorie, v. 22 (1991), p. 273-286. Duncker \& Humblot, Berlin 41.

LUHMANN, N. Gibt es in unserer Gesellschaft noch unverzichtbare Normen? Heidelberg: Müller, Heidelberger Universitätsreden, Bd 4. 1992a.

LUHMANN, N. “Zur Einführung”. In: NEVES, Marcelo. Verfassung und Positivität des Rechts in der peripheren Moderne: Eine theoretische Betrachtung und eine Interpretation des Falls Brasilien. Berlin: Duncker und Humblot, 1992b, p. 1-4.

LUHMANN, N. Das Recht der Gesellschaft. Frankfurt: Suhrkamp, 1993a.

LUHMANN, N. "Subjektive Rechte: Zum Umbau des Rechtsbewußtseins für die moderne Gesellschaft”. In: LUHMANN, N. Gesellschaftstruktur und Semantik: Studien zur Wissenssoziologie der modernen Gesellschaft. v. 2. Frankfurt: Suhrkamp, 1993b, p. 45-105.

LUHMANN, N. Soziologische Aufklärung 6: Die Soziologie und der Mensch. Opladen: Westdeutscher Verlag, 1995a.

LUHMANN, N. (1995b) "Das Paradox der Menschenrechte und drei Formen seiner Entfaltung”. In: LUHMANN, N. Soziologische Aufklärung, v. 6: Die Soziologie und der Mensch. Opladen: Westdeutscher Verlag, 1995a, p. 229-236.

LUHMANN, N. (1995c) “Inklusion und Exklusion”. In: LUHMANN, N. Soziologische Aufklärung, v. 6: Die Soziologie und der Mensch. Opladen: Westdeutscher Verlag (1995a, p. 237-264). 
- PEDRO HENRIQUE RIBEIRO

LUHMANN, N. (1995d) “Die Form “Person””. In: LUHMANN, N. Soziologische Aufklärung, v. 6: Die Soziologie und der Mensch. Opladen: Westdeutscher Verlag (1995a, p. 142-155).

LUHMANN, N. Die Gesellschaft der Gesellschaft. Frankfurt a. M.: Suhrkamp, 1997.

LUHMANN, N. “Quod omnes tangit. Remarks on Jürgen Habermas's legal theory”. In: ROSENFELD, M.; ARATO, A. (Ed.) Habermas on law and Democracy: critical Exchanges. Berkeley: University of California Press, 1998.

LUHMANN, N. “Jenseits der Barberei” In: Gesellschaftsstruktur und Semantik Gesellschaftsstruktur und Semantik - Studien zur Wissenssoziologie der modernen Gesellschaft. v. 4. Frankfurt a. M.: Suhrkamp, 1999, p. 138-150.

LUHMANN, N. Die Politik der Gesellschaft. Frankfurt: Suhrkamp, 2000a.

LUHMANN, N. “Der Fußsball”. In: GENTE, P.; PARIS, H.; WEINMANN, M. (Ed.). Short Cuts. Frankfurt a. M.: Zweitausendeins, 2000b, p. 88-90 [originally published in the journal: FAZ., 4.7.1990.]

LUHMANN, N. Einführung in die Theorie der Gesellschaft. Heidelberg: Carl-Auer, 2005.

LUHMANN, N. (2009[1970]) “Soziale Aufklärung”. In: LUHMANN, N. Soziologische Aufklärung: Aufsätze zur Theorie sozialer Systeme. v. 1. 8. ed. Wiesbaden: VS Verlag, 2009, p. 83-115.

MALTBY, E. A new and complete Greek Gradus, or Poetical Lexicon, or The Greek Language. An English-Greek vocabulary and a Treatise on some of the principal rules for ascertaining the quantities of syllables. London: G. Woodfall (digitalized by Virginia University and Google-Books), 1830.

MARQUES, E. C. L. “Urban Poverty, Segregation and Social Networks in São Paulo and Salvador, Brazil”. In: International Journal of Urban and Regional Research, 2016, v. 39, n. 6: 1067-108.

MASCAREÑO, A.; CHERNILO, D. “Obstacles and Perspectives of Latin American Sociology: Normative Universalism and Functional Differentiation”, Soziale Systeme, 2009, 15 (1): 72-96.

MERTON, R. Sociologia: Teoria e Estrutura. São Paulo: Mestre Jou, 1968.

MEYER, C. "Das Publicum als Instrument spätmittelalterlicher Justiz”. In: KINTZINGER, M.; SCHNEIDMÜLLER, B. (Ed.), Politische Öffentlichkeit im Spätmittelalter. Ostfildern: Thorbecke, 2011, p. 87-145.

MOISÉS, J. A. Os Brasileiros e a Democracia: bases sócio-políticas da legitimidade democrática. São Paulo: Ática, 1995.

MOYN, S. The Last Utopia: Human Rights in History. Cambridge, Mass.: Harvard University Press, 2010.

MÜLLER, F. Wer ist das Volk? Die Grundfrage der Demokratie - Elemente einer Verfassungstheorie VI. Berlim: Duncker und Humblot, 1997.

MÜLLER, F. Demokratie in der Defensive: funktionelle Abnutzung - soziale Exklusion - Globalisierung. Berlim, Duncker und Humblot (Elemente einer Verfassungstheorie VII - Schriften zur Rechtstheorie; Heft 197), 2001.

MÜLLER, K. Anstoß und Gericht: ein Studie zum jüdischen Hintergrund des paulinischen Skandalon-Begriffs. München: Kösel, 1969. 
NAFARRATE, J. T.; MANSILLA, D. R. “La Recepción del Pensamiento de Niklas Luhmann en América Latina”. In: FARIAS, I.; OSSANDON, J. (Ed.). Observando Sistemas. Nuevas apropiaciones y usos de la teoría de Niklas Luhmann. RIL: Santiago, 2006, p. 55-70.

NASSEHI, A. “Inklusion, Exklusion, Ungleichheit. Eine kleine theoretische Skizze” In: THOMAS, S. (Ed.). Differenzierung und soziale Ungleichheit. Die zwei Soziologien und ihre Verknüpfung. Frankfurt a.M.: Humanities Online, 2004, p. 323-352.

NASSEHI, A. “Rezeption: Soziologie”. In: OLIVER, J.; ARMIN, N. et al.(Ed.). Luhmann Handbuch: Leben, Werk, Wirkung. Stuttgart: J. B. Metzler, 2012.

NAZ, R. “Scandale” In: NAZ, R. Dictionnaire de Droit Canonique. I-VII, col. Encyclopédie des sciences ecclésiastiques. Paris: Letouzey \& Ané, 1965, p. 877-878.

NEMO-PEKELMANN, C. "Scandale et vérité dans la doctrine canonique médiévale (XII e - XIII e siècles)”. Revue historique de droit français et étranger (1922-), 2007, v. 85, n. 4, p. 491-504.

NEVES, M. Verfassung und Positivität des Rechts in der peripheren Moderne: Eine theoretische Betrachtung und eine Interpretation des Falls Brasilien. Berlin: Duncker und Humblot, 1992.

NEVES, M. "Entre Subintegração e Sobreintegração: a cidadania inexistente”. In: DADOS - Revista de Ciências Sociais, v. 37, n. 2, p. 253-276. Rio de Janeiro: Iuperj, 1994.

NEVES, M. “Do pluralismo jurídico à miscelânea social: o problema da falta de identidade da(s) esferas de juridicidade na modernidade periférica e suas implicações na América Latina”. In: Direito e Debate, 1995, ano V, n. 15, p. 7-37. Ijuí: Universidade de Ijuí.

NEVES, M. Entre Têmis e Leviatã: uma relação difícil. O Estado Democrático de Direito a partir e além de Luhmann e Habermas. [tradução do autor] Martins Fontes: São Paulo, 2006.

NEVES, M. A Constitucionalização Simbólica. São Paulo: Martins Fontes, 2007a.

NEVES, M. “The symbolic force of human rights” In: Philosophy \& Social Criticism, 2007b, v. 33, Issue 4, p. 411-444.

NEVES, M. Transconstitutionalism. Oxford: Portland: Oregon: Hart, 2013.

NEVES, M. "Ideas in Another Place? Liberal Constitution and the Codification of Private Law in the Turn of the $19^{\text {th }}$ Century in Brazil”. In: POLOTTO, M. R.; KEISER, T.; DUVE, T.(Eds.) Derecho Privado y Modernización. América Latina y Europa en la Primera Mitad del Siglo XX. Berlin: Max Planck Institute for European Legal History, 2015.

KEISER, T.; DUVE, T. (Ed.) Derecho Privado y Modernización. América Latina y Europa en la Primera Mitad del Siglo XX. Berlin: Max Planck Institute for European Legal History, 2015.

O’DONNEL, G. A Democracia no Brasil: dilemas e perspectivas. São Paulo: Vértice, 1988.

O’DONNELL, G.; SCHMITTER, P. Transições do Regime Autoritário: primeiras conclusões. São Paulo: Vértice, 1988.

O’DONNELL, G. "Poliarquias e a (in)efetividade da lei na América Latina: uma conclusão parcial”. Tradução Otacilio Nunes. In: MENDES, J. E.; O’DONNELL, G.; PINHEIRO, P. S. Democracia, violência e injustiça: o não-estado de direito na América Latina. São Paulo: Paz e Terra, 2000. 
- PEDRO HENRIQUE RIBEIRO

O’DONNELL, G. “Why The Rule of Law Matters”. Journal of Democracy. Baltimore: Oct 2004, v. 15, Iss. 4; p. 32, 15 p.

OPITZ, S. “Exklusion. Grenzgänge des Sozialen”. In: MOEBIUS, S.; RECKWITZ, A. (Ed.). Poststrukturalistische Sozialwissenschaften. Frankfurt a.M.: Suhrkamp, 2008, p. 175-193.

PARSONS, T. "Equality and Inequality in Modern Society - or: Social Stratification revisited”. In: Sociological Inquiry. 1970, n. 40, issue 2, p. 13-72.

PIEVATOLO, M. C. “Scandalum Acceptum and Scandalum Datum: Kant's Non-Interventionism In The Fifth Preliminary Article of the Perpetual Peace”. Scienza \& Politica, v. 24, n. 48, 2013.

PRADO JR., C. (1996[1942]) Formação do Brasil Contemporâneo. 11. ed. São Paulo: Brasiliense, 1996.

RADEMACHER, F. J. (2006). “Assymetrien des globalen Reichtums: Die Brasilianisierung der Welt” (An interview, questions by Fritz R. Glunk.). In: Die Gazette, N. 10, 2006.

REX GALINDO, D. "Para evitar escándalos: Conflictos internos y acusaciones públicas en la Provincia Franciscana de Michoacán, siglo XVII”. Paper presented on the XIX Congreso Del Instituto Internacional De Historia Del Derecho Indiano. Berlin, 2016.

RIBEIRO, P. H. “Luhmann fora do Lugar? Como a "condição periférica” da América Latina impulsionou deslocamentos na teoria dos sistemas”. Revista Brasileira. Ciências. Sociais. v. 28, n. 83, p. 105-123, 2013.

RIBEIRO, P. H.; EGIO, J. L. (2018 forthcomming) “Skandal und Menschenrechte: Reflexionen über mögliche Zusammenhänge iberoamerikanischer Früher Neuzeit mit den zeitgenössischen Debatten über Menschenrechte”. In: KÖHLER, S.; SCHAFFRICK, M. Wie kommen die Rechte des Menschen in die Welt? (Siegen: Winter Universitätsverlag in der Reihe Siegen. Beiträge zur Literatur-, Sprach- und Medienwissenschaft. Eine Schriftenreihe der Universität Siegen. Edited by Walburga Hülk, Georg Stanitzek und Niels Werber.) In press.

RICUPERO, B. “Da formação à forma. Ainda as 'idéias fora do lugar”. Lua Nova, 2008, 73, p. 59-69.

ROCHA, J. C. de C. “A guerra de relatos no Brasil contemporâneo. Ou ,A dialética da marginalidade“” Revista Letras (UFSM), 2004, v. 28-29, jan./dez.

RODRIGUEZ, D. M. “Los limites del estado em la sociedad mundial: de la política al derecho”. In: NEVES, M. Transconstitucionalidade do direito: novas perspectivas dos conflitos entre ordens jurídicas. São Paulo: Quartier Latin/Daad, 2010.

SALA-MOLIN, L. Le Code Noir ou le calvaire de Canaan. Paris: PUF Quadrige, 1987.

SALA-MOLIN, L. The Dark Side of the Light. Slavery and the French Enlightenment. Translate by John Conteh-Morgan. Minneapolis: University of Minnesota Press, 2006.

SANTIAGO, S. (2002) “Intérpretes do Brasil - Prefácio”. In: Silviano Santiago (Ed.) Intérpretes do Brasil. v. I. Rio de Janeiro: Nova Aguilar S.A., 2002, p. Xv-xlviii.

SANTOS, L. A. de C. “O pensamento sanitarista na Primeira República: Uma ideologia de construção da nacionalidade”. Dados. Revista de Ciências Sociais. Rio de Janeiro, 1985, v. 28, n. 2, p. 193-210. 
SCHALK, F. “Aufklärung”. In: JOACHIM, R. et al (Ed.) Historisches Wörterbuch der Philosophie. Darmstadt: Wissenschaftliche Buchgesellschaft, 1971, p. 619 f.

SCHNEIDER, N. “Demokratien im Wandel: Wie soziale Ungleichheit in Brasilien ab- und in Deutschland zunimmt”. In: Globkult Magazin: Politik, Gesellschaft, Kultur und Geschichte. - 12.4.2011. - URL: https://kops.uni-konstanz.de/handle/123456789/22557. Access in: 18 aug. 2020.

SCHNEIDER, N. "Ambivalenzen der brasilianischen Vergangenheitspolitik und Erinnerungskultur”. In: PETERS, S.; BURCHARDT, H. J.; ÖHLSCHLÄGER, R. (Ed). Geschichte wird gemacht: Vergangenheitspolitik und Erinnerungskulturen in Lateinamerika / - Baden-Baden: Nomos, 2015. - (Studien zu Lateinamerika; 30), p. 71-86.

SCHROER, M. “Funktionale Differenzierung versus soziale Ungleichheit”. In: KNEER, G; MOEBIUS, S. (Ed.). Soziologische Kontroversen: Beiträge zu einer anderen Geschichte der Wissenschaft des Sozialen. Frankfurt, Suhrkamp, 2010.

SCHROER, M. "Soziologie der Aufmerksamkeit: Grundlegende Überlegungen zu einem Theorieprogramm”. In: KZfSS Kölner Zeitschrift für Soziologie und Sozialpsychologie, v. 66, n. 2, p. 193-218, Jun. 2014.

SCHWARCZ, L. M. O Espetáculo das Raças: cientistas, instituições e questão racial no Brasil do século XIX. São Paulo: Companhia das Letras, 1993.

SCHWARCZ, L. M. “Nem preto nem branco, muito pelo contrário: cor e raça na intimidade”. In: SCHWARCZ, L. M. (Ed.) História da vida privada no Brasil, v. 4. São Paulo: Companhia das Letras, 1998.

SCHWARZ, R. "Por que 'ideias fora do lugar?”. In: SCHWARZ, R. Martinha versus Lucrécia: ensaios e entrevistas. São Paulo, Companhia das Letras, 2012.

SCHWARZ, R. “As idéias fora do lugar”. In: SCHWARZ, R. Ao vencedor as batatas, 5. ed. São Paulo: Editora 34, 2005.

SCHWINN, T. "Soziale Ungleichheit und funktionale Differenzierung: Wiederaufnahme einer Diskussion” Zeitschrift für Soziologie. 1998, 27:1, p. 3-27.

SEILS, M. “Ärgernis”. In: RITTER, J. et al (Ed.) Historisches Wörterbuch der Philosophie. Darmstadt: Wissenschaftliche Buchgesellschaft, 1971, p. 504-505.

SILVA, V. A. da. "O Judiciário e as políticas públicas: entre transformação social e obstáculo à realização dos direitos sociais”. In: SOUZA NETO, C. P. de.; SARMENTO, D. Direitos sociais: fundamentação, judicialização e direitos sociais em espécies. Rio de Janeiro: Lumen Juris, 2008, p. 587-599.

SKIDMORE, T. E. Black into White: Race and Nationality in Brazilian Thought. New York: Oxford University Press, 1974.

SOUZA, J. A Modernização Seletiva: uma reinterpretação do dilema brasileiro. Brasília: Editora Universidade de Brasília, 2000.

SOUZA, J. "Prefácio: Invisibilidade da desigualdade brasileira”. In: SOUZA, J. (Ed.) A invisibilidade da desigualdade brasileira. Belo Horizonte: Editora UFMG, 2006. 
STÄHELI, U. “Die Sichtbarkeit sozialer Systeme: Zur Visualität von Selbst- und Fremdbeschreibungen”. In: Soziale Systeme, 2007, 13, Suppl. 1+2, p. 70-85.

STÄHELI, U. “Die Nachträglichkeit der Semantik - Zum Verhältnis von Sozialstruktur und Semantik”, In: Soziale Systeme, 1998, 4, p. 2, S. 315-340.

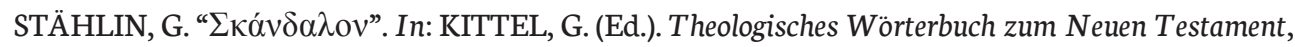
v. 7. Stuttgart: K. Kohlhammer Verlag, 1961.

STÄHLIN, G. Skandalon. Die Geschichte eines biblischen Begriffs. Gütersloh: "Der Rufer" Evangelischer Verlag, 1930.

STAM, R.; SHOHAT, E. Race in Translation: Culture Wars Around the Postcolonial Atlantic. New York: New York University Press, 2012.

STICHWEH, R. "Inklusion/Exklusion, funktionale Differenzierung und die Theorie der Weltgesellschaft”. In: Soziale Systeme: Zeitschrift für soziologische Theorie 3. Opladen: Leske und Budrich, 1997, p. 123-36.

STICHWEH, R. Inklusion und Exklusion: Studien zur Gesellschafttheorie. Bielefeld:Transcript Verlag, 2005.

STICHWEH, R. “Towards a General Theory of Function System Crises”. In: TEUBNER, G.; KJAER, P.; FEBBRAJO, A. The Financial Crisis in Constitutional Perspective: The Dark Side of Functional Differentiation. Oxford: Hart Publishing, 2011, p. 43-60.

TAVOLARO, S. B. de F. Cidadania e modernidade no Brasil (1930-1945): uma crítica a um discurso hegemônico. São Paulo: Annablume, 2011.

TELLES, V. S. Direitos Sociais - afinal do que se trata? Belo Horizonte: UFMG, 2006.

TEUBNER, G. "Die anonyme Matrix: Zu Menschenrechtsverletzungen durch "private” transnationale Akteure”. In: Der Staat: Zeitschrift für Staatslehre und Verfassungsgeschichte, deutsches und europäisches öffentliches Recht 44, 2006, p. 161-187.

TEUBNER, G. “A Constitutional Moment? The Logics of 'Hitting the Bottom”. In: TEUBNER, G..; KJAER, P.; FEBBRAJO, A. The Financial Crisis in Constitutional Perspective: The Dark Side of Functional Differentiation. Oxford: Hart Publishing, 2011.

TEUBNER, G. Verfassungsfragmente: Gesellschaftlicher Konstitutionalismus in der Globalisierung. Frankfurt a. M.: Suhrkamp, 2012.

THOMPSON, J. B. Political Scandal: Power and Visibility in the Media Age. Nortfolk: Polity Press, 2000. TOMASI di LAMPEDUSA, G. Il Gattopardo. (Italian Text with commentaries in German by Kerstin Marfordt - Ed.). Suttgart: Philipp Reclam jun, 2011.

TUSHNET, M. Taking the Constitution away from the Courts. Princeton: Princeton University Press, 2000.

VESTING, T. "Ende der Verfassung? Zur Notwendigkeit der Neubewertung der symbolischen Dimension der Verfassung in der Postmoderne”. In: VESTING, T.; KORIOTH, S. (Ed.) Der Eigenwert des Verfassungsrechts. Was bleibt von der Verfassung nach der Globalisierung? Tübingen: Mohr Siebeck, 2011, p. 71-94. 
VESTING, T. "Nachbarschaft: Grundrechte und Grundrechtstheorie in der Kultur der Netzwerke”. In: VESTING, T.; KORIOTH, S.; AUGSBERG, I. (Ed.). Grundrechte als Phänomene kollektiver Ordnung: Zur Wiedergewinnung des Gesellschaftlichen in der Grundrechtstheorie und Grundrechtsdogmatik. Tübingen: Mohr Siebeck, 2014.

VESTING, T. Die Medien des Rechts: Computernetzwerke. Tübingen: Velbrück Verlag, 2015.

VIANNA, O. (1973[1920]). Populações Meridionais do Brasil. v. 1. Rio de Janeiro: Paz e Terra, 1973.

VILLAS BÔAS FILHO, O. Teoria dos sistemas e o direito brasileiro. São Paulo: Saraiva, 2009.

ZWEIG, S. (2013[1941]) Brasilien - Ein Land der Zukunft. Berlin: Insel Verlag, 2013. 